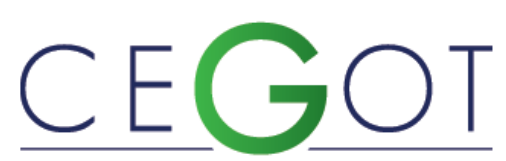

Centro de Estudos de Geografia e Ordenamento do Território
Marques da Costa, CARlos

CESUR, Instituto Superior Técnico - Universidade de Lisboa Av. Rovisco Pais, 1049-001 Lisboa ccarlos.mc@gmail.com

\author{
NUNeS da Silva, FERnANDO \\ CESUR, Instituto Superior Técnico - Universidade de Lisboa \\ Av. Rovisco Pais, 1049-001 Lisboa \\ fnsilva@tecnico.ulisboa.pt \\ TEIXEIRA, PEDRo \\ CESUR, Instituto Superior Técnico - Universidade de Lisboa \\ Av. Rovisco Pais, 1049-001 Lisboa \\ pmbteixeira@gmail.com
}

\title{
O Plano Geral de Urbanização de Vendas Novas: Uma experiência inovadora nos anos
} 1980.

Vendas Novas General Urbanization Plan: An innovative experience in the 1980s.

Referência: Marques da Costa, Carlos; Nunes da Silva, Fernando; Teixeira, Pedro (2019). Agriculturización, impactos ambientales y zonificación ecológica en el partido de tres arroyos (provincia de Buenos Aires, argentina). Período 2002 y 2017. Revista de Geografia e Ordenamento do Território (GOT), n.o 18 (Dezembro). Centro de Estudos de Geografia e Ordenamento do Território, p. 5-37, dx.doi.org/10.17127/got/2019.18.001

\section{RESUMO}

O Plano Geral de Urbanização de Vendas Novas constitui um trabalho inovador no planeamento urbanístico português. Desde logo releva o facto da sua elaboração ter sido cometida aos alunos de um curso universitário, coordenados pelo Professor Manuel da Costa Lobo, ele próprio o dinamizador e responsável pela primeira experiência de formação pós-graduada em Portugal no domínio do urbanismo. Por outro lado, o PGU resultou de uma reflexão a nível regional sobre o papel que Vendas Novas poderia desempenhar no contexto das políticas de ordenamento do território o que, à época, era uma abordagem inovadora na elaboração de um plano de urbanização. Por fim, o Plano veio a adoptar uma formalização mais flexível em relação ao que a legislação consagrava, nomeadamente pela utilização de conceitos como o de usos mistos do solo e a definição de unidades de planeamento (mais tarde consagrados na legislação) e contendo orientações morfotipológicas para os espaços a urbanizar.

Palavras-chave: Planeamento Urbano; Urbanismo; Vendas Novas; Mestrado em Planeamento Regional e Urbano.

\section{ABSTRACT}

The Urban Plan of Vendas Novas (PGUVN) is consider an innovative work in the Portuguese planning experience. Firstly because a group of students of a post-graduation course developed it, coordinated by Professor Manuel da Costa Lobo, himself the responsible for 
that first course in urban planning in Portugal. On the other hand, the PGUVN result from a reflexion at regional level of the role of Vendas Novas in the context of national regional policies, which, at the time been, was a quite innovative approach in an urban plan. Finely, the Plan adopt a more flexible format then the existing legal framework, namely using the concepts of mix land uses and the definition planning units (latter on incorporated in the Portuguese planning legislation) and defining morphological and typological orientations for the areas to be urbanized.

Keywords: Urban Planning; Urbanism; Vendas Novas; Master in Urban and Regional Planning.

\section{Nota Prévia}

O Plano Geral de Urbanização de Vendas Novas (PGUVN), elaborado pela então Universidade Técnica de Lisboa em 1979/80, constitui "uma primeira experiência de prestação de serviço ao exterior realizado pela Universidade Técnica de Lisboa (UTL), conjuntamente com o ensaio pedagógico de envolvimento dos alunos do Curso de pósgraduação em Planeamento Regional e Urbano, que decorreu em 1978/79" (Lobo, 1979).

Esta experiência foi possível concretizar porque, anteriormente, a Câmara Municipal de Vendas Novas tinha contatado o Prof. Manuel da Costa Lobo, enquanto profissional liberal, para elaborar o referido Plano. O facto do Professor ser simultaneamente o director do curso de pós-graduação, pemitiu que este acordasse com a então Direcção-Geral do Planeamento Urbanístico (DGPU) e a Câmara Municipal de Vendas Novas (CMVN), que o Plano fosse elaborado pelos alunos do curso de pós-graduação, sob a supervisão do seu corpo docente e a coordenação do Prof. Costa Lobo.

Estamos assim em presença de uma situação duplamente inovadora no contexto da época. Por um lado, com a compreensão do organismo que tutelava os processos de planeamento urbano, a DGPU, e a concordância da Câmara Municipal de Vendas Novas, foi possível, no âmbito de um curso de pós-graduação ${ }^{1}$, a UTL elaborar, pela primeira vez, um trabalho profissional para a comunidade. Por outro lado, essa experiência pedagógica, que associava um trabalho universitário multidisciplinar a uma intervenção prática, era sujeita a uma monitorização técnica e processual por parte da administração central e de um município.

\footnotetext{
${ }^{1}$ Em 1970 não existiam em Portugal cursos de mestrado, pelo que o próprio curso de pós-graduação era, em si mesmo, a primeira tentativa de formalizar uma formação especializada para licenciados, constituindo uma inovação no panorama universitário português.
} 
Se, por um lado, esta situação singular se ficou a dever à concordância das duas entidades intervenientes na adjudicação do PGUVN, temos de reconhecer que, na génese desta situação, está a capacidade de inovação pedagógica do Prof. Costa Lobo, personalidade académica incontornável na história do urbanismo português na segunda metade do séc. XX e na primeira década deste século.

Também de um ponto de vista metodológico o PGUVN representa uma abordagem inovadora, ao incluir uma análise concelhia e regional, "para bem enquadrar o fenómeno urbano a estudar, e para salvaguardar as áreas envolventes dos centros, que frequentemente tendem a deteriorar-se com a entrada em vigor de planos incidindo em áreas limitadas". Este extrato retirado do preâmbulo do relatório de Análise do Plano, de junho de 1979, demonstra outra das particularidades deste estudo, ao recusar abordar o território urbano e periurbano de Vendas Novas, numa perspetiva confinada aos limites administrativos do concelho. Pelo contrário, parte de uma análise mais abrangente (regional), capaz de permitir, ainda que com algumas limitações, um enquadramento das propostas de ordenamento contidas no PGUVN no espaço que polariza ou de que sofre as influências. Este tipo de preocupação só veio a ser consagrada na legislação urbanística de 1982, para os Planos Directores Municipais, e em 1999 para os outros instrumentos de gestão territorial. Note-se no entanto que desde o quadro legal de 1971 (o primeiro que transpôs para a legislação portuguesa os princípios urbanísticos do Movimento Moderno), onde expressamente se refere que podem ser igualmente elaborados planos gerais de urbanização "das áreas territoriais em que a estrutura urbana justifique planos de conjunto abrangendo vários centros urbanos e zonas rurais intermédias ou envolventes" ${ }^{2}$. Terá sido exactamente esta possibilidade legal que foi utilizada no caso de Vendas Novas (processo de planeamento iniciado muito antes da legislação de 1982) e mais tarde no PGU do concelho de Évora, no que viria a ser o primeiro PDM antes desta figura estar consagrada em lei.

A necessidade de uma análise à escala regional, não foi assim esquecida neste trabalho, embora os dados então disponíveis não permitissem retirar linhas de ação claras, que pudessem influenciar (balizando ou condicionando) as propostas para o território de intervenção do Plano. No entanto, não deixa de ser assinalável esta leitura abrangente do território em termos do seu ordenamento, a qual veio a ser mais tarde institucionalizada,

\footnotetext{
${ }^{2}$ Ver Decreto-Lei n.o 560/71, de 17 de dezembro, art.o 2.o, alínea c).
} 
fazendo hoje parte integrante do quadro jurídico português, nomeadamente a partir da primeira publicação da legislação relativa ao Plano Director Municipal (Decreto-Lei n.으 208/82, de 26 de Maio).

Por todas estas razões, volvidos que são 36 anos sobre a sua elaboração, resulta totalmente pertinente analisar o PGU de Vendas Novas, não só pelo seu carácter inovador de um ponto de vista científico e técnico, mas também pela possibilidade de confrontarmos as suas propostas com a respetiva execução.

O trabalho que agora se apresenta implica, desde logo, uma permanente contextualização dos seus vários momentos, tendo em conta o tempo que decorreu desde a sua elaboração até à atual fase de análise. Na realidade, face às transformações económicas, sociais e políticas com expressão no território, verificadas nas últimas décadas em Portugal e na Europa, o presente trabalho centra-se mais na análise do que o PGUVN influiu na consolidação urbana do concelho de Vendas Novas - uma vila situada na região do Alentejo, a $100 \mathrm{~km}$ a sul de Lisboa - do que numa avaliação teórica dos seus pressupostos, muito marcados pelo contexto da época em que foi elaborado o Plano. Essas transformações, numa economia aberta e frágil como a portuguesa, colocam sempre grandes problemas às decisões de desenvolvimento estratégico delineadas pela administração central, quase sempre sem consequências de maior no território.

Vendas Novas não foi exceção a esta realidade e, ao constatarmos os sucessos e os insucessos das políticas de ordenamento propostas, estamos a participar numa análise muito mais alargada, abrangendo muitos outros domínios de actuação das administrações central e local.

\section{Enquadramento Legal do Plano}

O PGU de Vendas Novas foi elaborado de acordo com o Decreto-Lei n. 560/71, "numa interpretação que se considera não abusiva da letra da lei, procurando mais o seu espírito" (Lobo, 1979), motivo pelo qual, na sua fase de análise, o Plano se estende ao concelho e à região.

O Decreto-Lei n. 9 560/71 constitui um marco determinante no ordenamento jurídico nacional do urbanismo, em particular no que diz respeito ao conteúdo dos planos, 
terminando com a figura dos anteplanos de urbanização e aclarando os contornos e o conteúdo técnico dos Planos Gerais de Urbanização.

$\mathrm{Na}$ realidade, até essa data, "a maior parte dos trabalhos ficou-se pela elaboração de anteplanos de urbanização, sem que se tenha chegado a aprovar o plano geral subsequente, e foi pela provisão de anteplanos que se determinaram os contornos urbanísticos de numerosas localidades, pois uma vez aprovados pelo governo, eram de observância rigorosa" (Gonçalves, 1989).

Nesta legislação do início dos anos 1970, destaca-se ainda a publicação da Lei de Solos, Decreto-Lei n.o 576/70, de 24 de novembro, que veio impor regras no processo expropriatório, visando controlar a atividade especulativa das entidades privadas, dotando ainda o Estado de alguma capacidade pró-activa em termos de urbanização e ordenamento do território. Já em 1976 é publicada uma nova Lei de Solos, o Decreto-Lei n. 794/76, de 5 de Novembro, que prossegue a intenção "de reger a aquisição e a utilização de solos, para fins urbanísticos, tendo em mente os processos de expansão urbana dos aglomerados", corporizando de alguma forma o entendimento, dominante à época, sobre a necessidade do alargamento dos perímetros urbanos, como forma de promover "o adequado ordenamento do território para um equilibrado desenvolvimento socio-económico das suas diversas regiões", conforme se pode ler no seu art.o 1.ำ, o qual "sujeita a alteração do uso ou da ocupação dos solos para fins urbanísticos a autorização prévia da Administração".

Em 25 de novembro de 1977 é publicada a Lei n. 79/77, que define as atribuições das autarquias, bem como as competências dos órgãos autárquicos, constituindo o momento determinante para a afirmação do poder local democrático que, com a publicação deste diploma, inicia o seu percurso de autonomia e de emancipação face ao Estado central. Esse processo consolidou-se, dois anos mais tarde, com a publicação da Lei das Finanças Locais (Frade, 1999).

Ainda neste contexto, e para melhor compreendermos o enquadramento do PGU de Vendas Novas, não podemos deixar de referir os III e IV Planos de Fomento.

O III Plano de Fomento (1969-1973) chama a atenção, pela 1. a vez no nosso país, para o tema do ordenamento do território, apontando como medidas prementes reconduzir o crescimento de Lisboa - a capital do país - a níveis mais moderados, diminuir as 
divergências nos graus de desenvolvimento das várias regiões do país e redefinir o sistema urbano. No entanto, caberia apenas ao IV Plano de Fomento (1974-1979) - o último a ser elaborado na vigência do anterior regime - dar um conteúdo mais preciso às intenções enunciadas anteriormente e apontar as medidas de concretização de uma política de ordenamento do território, erigida como um dos seus objetivos básicos (FRADE, 1999). A Revolução do 25 de Abril de 1974, retirou-lhe capacidade de atuação, mas manteve-se como referência incontornável no processo legislativo relativo ao ordenamento do território que se lhe seguiu.

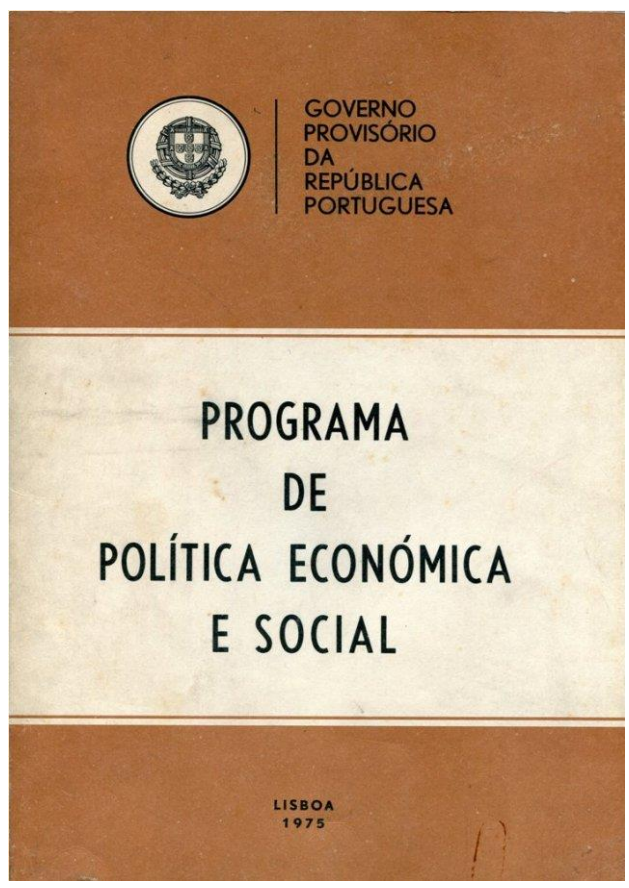

Fig. 1 - Capa do "Programa de Política Económica e Social”, Governo Provisório da Républica Portuguesa, Lisboa: Imprensa Nacional, 1975.

Cronologicamente, sucedeu-Ihe o Programa de Política Económica e Social, elaborado em princípios de 1975 por um conjunto de personalidades ligadas ao governo da altura. Melo Antunes, Rui Vilar, Vítor Constâncio e Maria de Lurdes Pintassilgo, foram os responsáveis por este documento que, segundo os seus autores, pretendia apenas "ser um ataque a alguns dos problemas imediatos e mais sérios da economia portuguesa e lançar as bases de uma transformação social do nosso país". Todavia, para alguns especialistas, este Programa 
constituía tão-somente uma versão actualizada do IV Plano de Fomento, justificada pelo novo enquadramento político resultante da restauração do regime democrático no país.

Não se justificando aqui uma análise detalhada dos Planos de Fomento, não deixam estes de ter alguma relevância para a compreensão dos cenários que fundamentaram a necessidade da elaboração do PGUVN, nomeadamente no que se refere à necessidade de desconcentrar a Área de Metropolitana de Lisboa e de promover a industrialização no norte do Alentejo, onde Vendas Novas viria a assumir um papel relevante.

\section{O Plano Geral de Urbanização de Vendas Novas}

\subsection{Fase de Análise}

A fase de Análise $^{3}$ do PGUVN é constituída por um conjunto de estudos sectoriais, que no seu todo caracterizam o território de intervenção. Apesar de se tratar de uma fase de levantamento, caracterização e diagnóstico da situação existente à data de elaboração do Plano, e das tendências de transformação verificadas no passado, o relatório interioriza, desde logo, algumas leituras do concelho que não decorrem exclusivamente da análise dos dados levantados e informação recolhida. Pelo contrário, o relatório explicita e assume um entendimento deste território face a Évora - a cidade capital da região do Alentejo - e a Lisboa, embora a sua fundamentação não seja desenvolvida no trabalho, situação perfeitamente normal se tivermos em conta que, à época, os modelos de desenvolvimento regional dominantes, mereciam uma aceitação técnica quase consensual.

As propostas de ordenamento do território fundamentam-se e traduzem sempre num modelo de desenvolvimento socio-económico, mesmo quando assumem um posicionamento defensivo, por razões políticas ou ideológicas.

Não é o caso do PGUVN, que se desenvolve num contexto político que em momento algum rejeita, e que, inclusive, permite a sua realização através do curso de Pós-Graduação em Planeamento Regional e Urbano da UTL, facto só possível dada a abertura política, então existente no país, à inovação administrativa e experimentação pedagógica.

\footnotetext{
${ }^{3}$ De acordo com o preconizado no Decreto-Lei n.o 560/71, o PGU de Vendas Novas organiza-se segundo dois documentos, um de levantamento e análise da situação existente e outro de carácter propositivo, seguindo a metodologia convencional à época na elaboração deste tipo de trabalhos.
} 
Seguindo o índice do relatório da fase de análise do Plano, retemos os pontos mais relevantes, de que se destaca o ponto 3 - Enquadramento na Região.

O Plano dá-nos de imediato o enquadramento em que foi realizado, através de algumas observações expressas logo no início do texto:

- "Como grandes faltas a reivindicar poderemos apontar para a ausência de uma estrutura regional atuante e eficiente na função horizontal de coordenação do ordenamento."

- "Além da falta de uma política de planeamento nacional, não existe um ordenamento agrário da zona (...) mas este não foi possível encarar no âmbito deste estudo, nomeadamente pela dificuldade de obter um cadastro estável, no período que temos atravessado de instabilidade da reforma agrária.."

Neste capítulo de análise, os autores (os alunos do Curso de Pós-graduação) referem que o trabalho que estão a desenvolver em paralelo para a sub-região Évora/Vendas Novas, "poderá abrir algumas pistas".

De facto, é a partir desta análise mais alargada do território, que surgem os primeiros cenários de intervenção para o aglomerado urbano de Vendas Novas, os quais vão sendo sucessivamente plasmados no relatório.

De um ponto de vista do ordenamento do território este facto assume a maior relevância, principalmente se nos situarmos no final da década de 1970, tendo como referência a comparação com outros planos então realizados que, na maioria dos casos, circunscreveram a análise ao perímetro urbano dos aglomerados.

Esta metodologia de abordagem está patente em todo o trabalho e constitui, quanto a nós, uma das suas mais-valias, já que todas as propostas partem de cenários que contemplaram, ainda que de forma não muito aprofundada, a própria área metropolitana de Lisboa.

Curiosamente, a análise efetuada ao concelho apontava para uma situação, o eixo Pegões (Canha)/Vendas Novas, com tal evidência que os autores do Plano sugeriram, ainda nesta primeira fase do Plano, a administração conjunta do processo de desenvolvimento destes dois aglomerados. Também se relevava a necessidade de parte do concelho de Palmela, nas áreas contiguas à freguesia da Landeira, integrasse esta área de gestão conjunta. "Nessa perspetiva poderia então vislumbrar-se um crescimento importante das atividades

\footnotetext{
${ }^{4}$ Neste período, e em particular no ano de 1975 , tem origem um vasto movimento popular de ocupação de terras no Alentejo, então propriedade de grandes latifundiários.
} 
económicas da área, bem ligado à solução viária e de infraestruturas, sem atropelos mútuos."

Não cabe aqui proceder a uma avaliação sistemática e profunda desta leitura do território, até porque a mesma não se veio a concretizar. No entanto, ficará pelo menos a dúvida sobre os resultados que se teriam verificado no seu desenvolvimento territorial, caso a mesma tivesse sido acolhida.

Mas se, neste caso, a análise desenvolvida e as propostas delas decorrentes não se concretizaram, no que se refere ao estudo efetuado sobre a estrutura fundiária, os resultados são completamente diferentes e de um rigor assinalável.

"A estrutura fundiária e os processos de parcelamento representam sempre, numa área urbana, um dos elementos determinantes da organização do território, e da forma das cidades." ( Costa Lobo, 1976: p15).

Mais uma vez, e no contexto temporal do Plano, estamos em presença de uma grande lucidez no que respeita à compreensão do território e das suas interrelações, que se vai refletir na proposta final, tendo por base um estudo do processo de parcelamento do território. Este estudo baseou-se no cadastro do Instituto Geográfico e Cadastral (IGC) de 1958, "a partir do qual" a equipa do Plano procedeu ao estudo da sua evolução fundiária e dos processos de loteamento verificados, o que permitiu "constatarem-se as interligações e conexões existentes na área de Vendas Novas entre o processo de urbanização e as alterações à estrutura fundiária processadas" (Lobo, 1979).

É extremamente interessante verificar, recorrendo aos meios tecnológicos de que hoje dispomos, que os esquemas interpretativos apresentados nesta fase de análise, respeitantes ao processo de subdivisão das propriedades iniciais que deram origem às formas de loteamento que hoje se detetam na área do PGUVN, vieram a confirmar-se plenamente, conforme podemos constatar face à sua sobreposição com a fotografia aérea. O rigor desta parte do estudo e a geometria do parcelamento fundiário, permitiram um controlo sobre o desenvolvimento dos posteriores processos de loteamento e de construção, que deram ao território a imagem e a ocupação que ainda hoje o caracterizam.

Outro dos aspetos interessantes a reter nesta fase do PGUVN, é o entendimento da equipa do Plano sobre o "valor económico-social e viabilidade ecológica do povoamento 
semiextensivo em Quintinhas" (Lobo, 1979). No trabalho de campo realizado no local, pôde observar-se como esta realidade é ainda bem visível em algumas parcelas do núcleo urbano, principalmente nas franjas das suas áreas consolidadas, que configuram, claramente, o que mais tarde se veio a denominar por situações urbano-rurais ou periurbana (Pereira e Nunes da Silva, 2008).

A análise desenvolvida no Plano mantem-se perfeitamente assertiva (e actual) nos longínquos anos 1980, quando afirma:

"A falta de terra fértil é superada pela definição material dos lotes, eliminando o desgaste erosivo das chuvadas pela retenção de terras e enriquecendo-as com matéria orgânica através de um trabalho persistente e prolongado.

São exemplo do sucesso conseguido nestes terrenos muitos pomares e hortas que emolduram Vendas Novas nas zonas dos antigos foros." (Costa Lobo, 1976: p33).

No que se refere à estrutura da sua forma urbana, Vendas Novas pode considerar-se como um núcleo que se desenvolve ao longo de uma estrada, a EN-4, como acontece em algumas povoações no Alentejo e, ainda mais frequentemente, no Ribatejo ${ }^{5}$.

Este núcleo de estrutura mais concentrada constitui o centro urbano do aglomerado, em torno do qual se localizam os espaços urbanos em formação ou ainda não completamente consolidados, em coexistência com as parcelas agrícolas, situação que confere a este território o aspeto de uma ocupação urbana dispersa e periurbana, que ainda hoje mantem.

Esta baixa densidade, resultado da existência de significativas áreas não loteadas dentro do perímetro urbano, associada à capacidade instalada e de expansão das redes de infraestruturas então existentes, conduziram a uma proposta de densificação do perímetro urbano abrangido pelo Plano.

A proposta de uso do solo, que se veio a consolidar na fase posterior do trabalho, sustentou-se basicamente em 4 pressupostos, uns mais objetivos que outros.

Nos cenários previsionais de crescimento demográfico, consideraram-se os resultados dos modelos matemáticos então aplicados à Área Metropolitana de Lisboa e à Sub-região de

\footnotetext{
5 “O traçado das vias principais opta pelo exterior dos núcleos populacionais em vez de os atravessar, como faziam os traçados antigos, o que atraindo diversas funções para a beira da estrada não deixa de ter reflexos negativos sobre a animação da parte central das cidades." SALGUEIRO, Teresa Barata (1987).
} 
Évora, ainda que, neste particular, o trabalho tenha assumido uma posição muito cautelosa, não optando por nenhum dos dois cenários considerados.

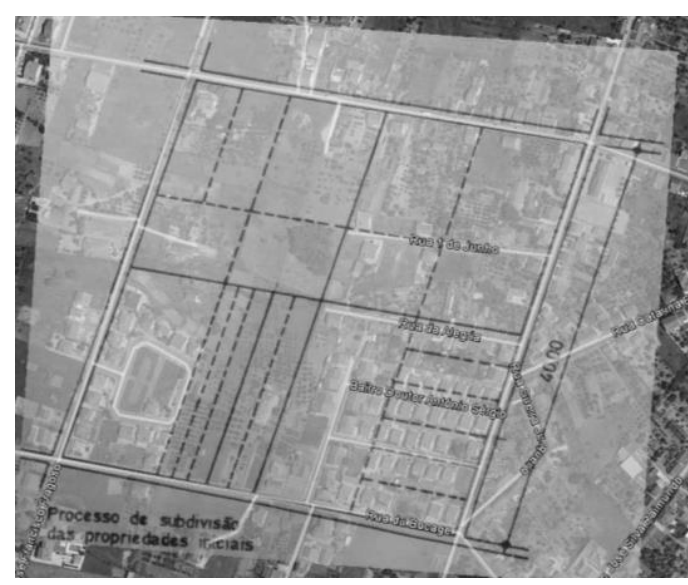

Fig. 2 - Malha reticulada proposta (1978) Fonte: Costa Lobo (1980)

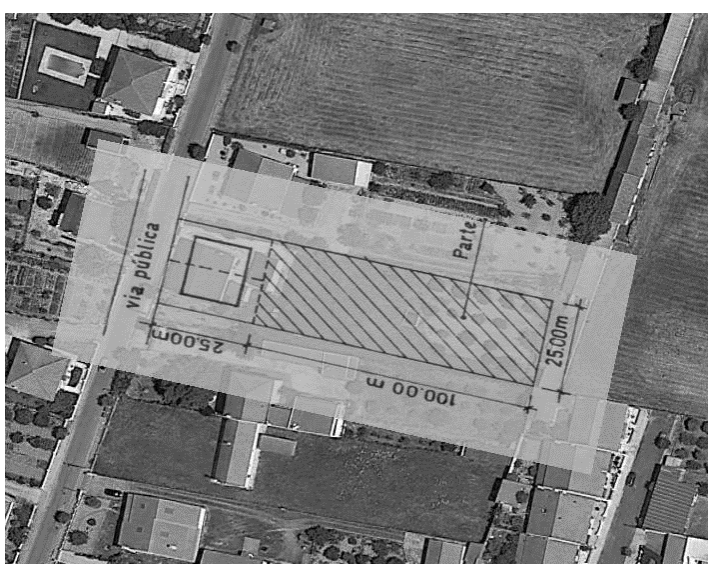

Fig. 4 - Exemplo de lote proposto (1978) Fonte: Costa Lobo (1980)

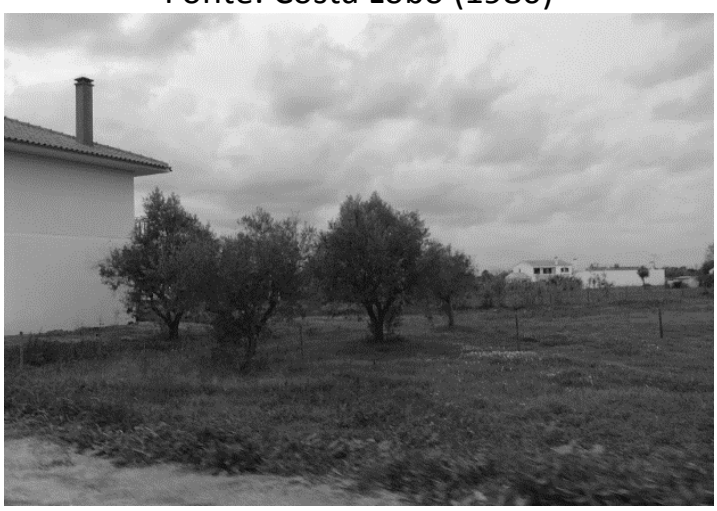

Fig. 6 - Registo fotográfico local

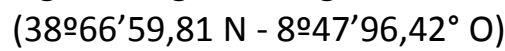

Fonte: Recolhido pelos autores (2019)

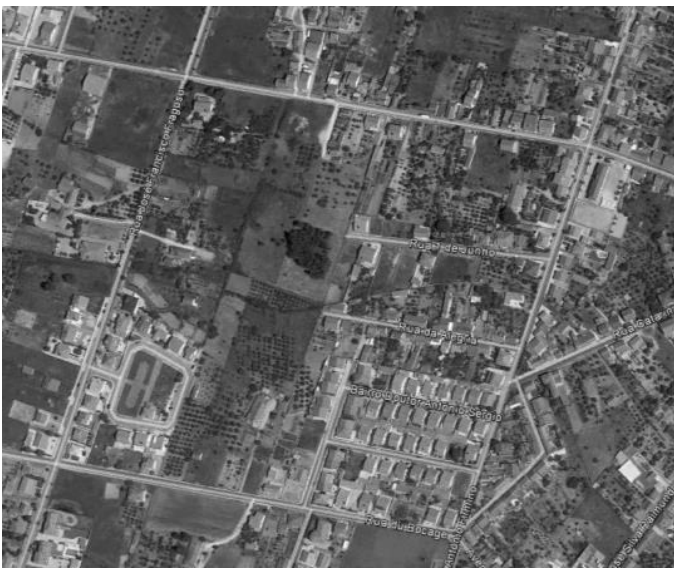

Fig. 3 - Malha reticulada existente (2016) Fonte: Google Earth (2016)

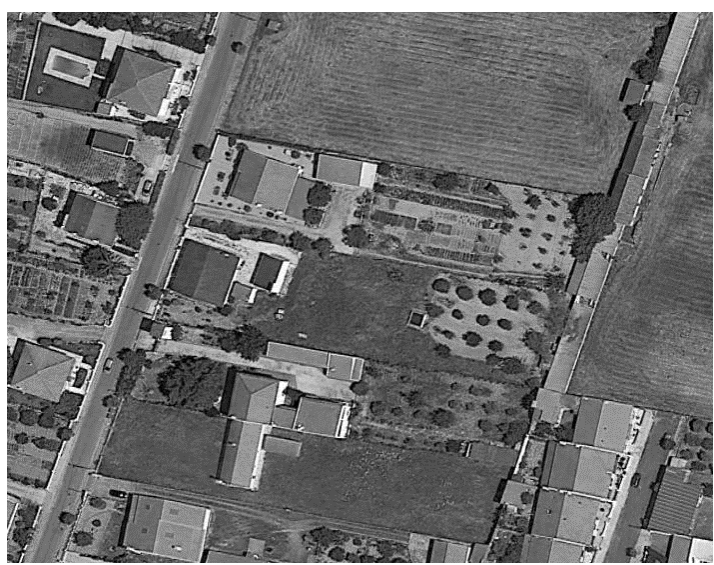

Fig. 5 - Exemplo de lote concretizado (2016) Fonte: Google Earth (2016)

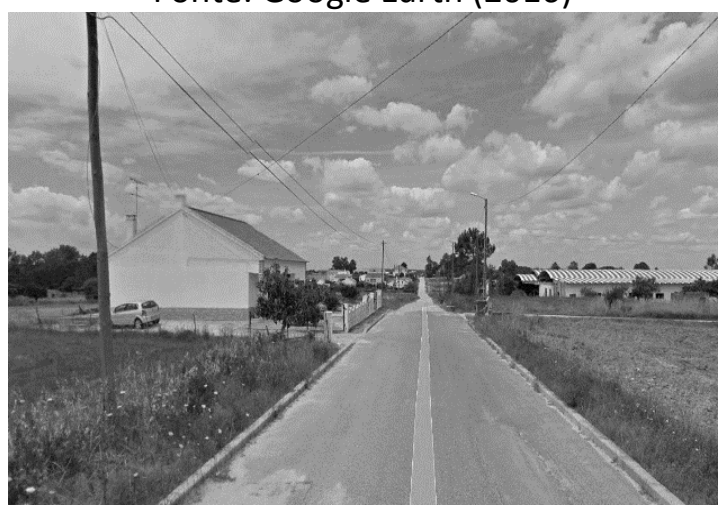

Fig. 7 - Registo fotográfico local (3840'19,62"N - 828'51,30"O)

Fonte: Recolhido pelos autores (2019) 


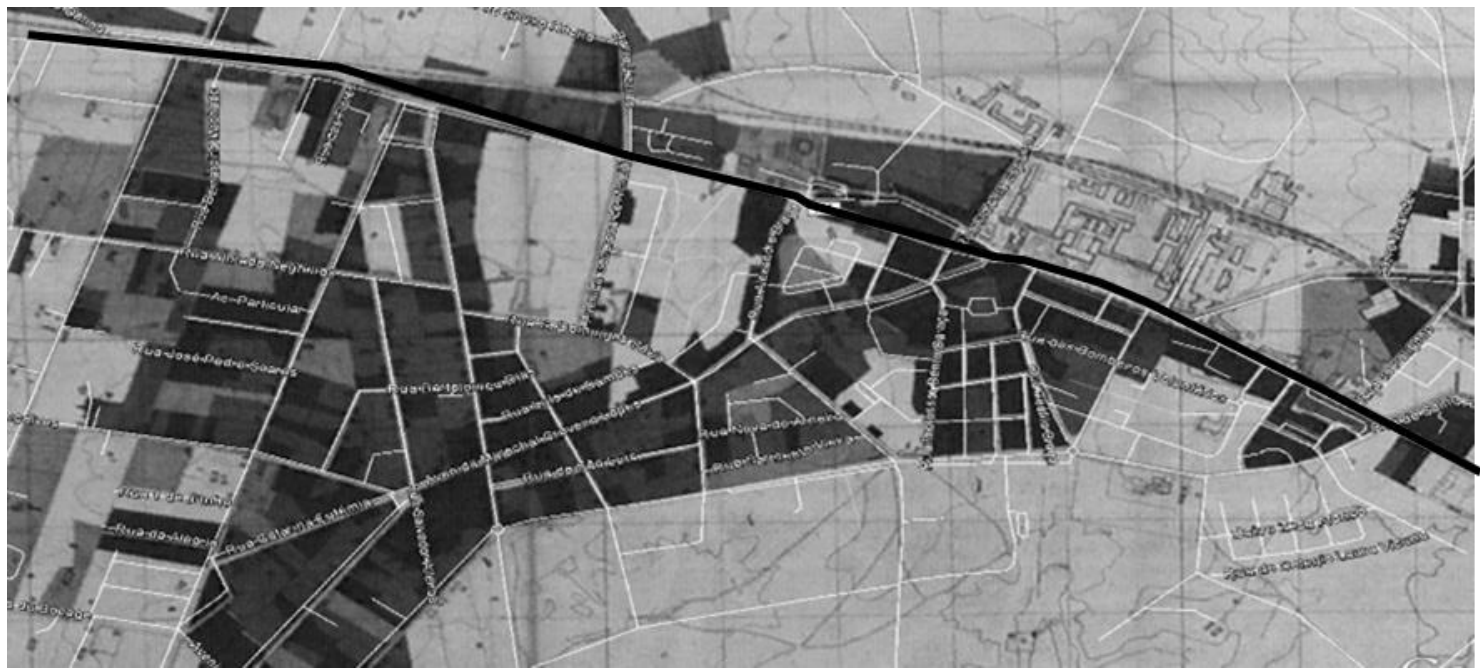

Fig. 8 - Planta do Registo Cadastral

Fonte: PGUVN (Costa Lobo, 1976)

Em contrapartida, e tendo por base o estudo que a equipa desenvolvia para a sub-região Évora/Vendas Novas, considerou-se que o crescimento do núcleo urbano de Vendas Novas se apoiaria preferencialmente na sua "relação" com Pegões.

Já no que se refere aos cenários de densificação do espaço urbano de Vendas Novas, apresentam-se as projeções demográficas que a justificavam, analisam-se as capacidades instaladas nas redes de infraestruturas urbanas $^{6}$ e, por fim, caracterizam-se as formas de ocupação do território, onde predomina um desenvolvimento irregular, "apresentando significativas diferenças de densidade, dependendo estas profundamente da proximidade da área central e das vias principais." (Costa Lobo, 1976: p44).

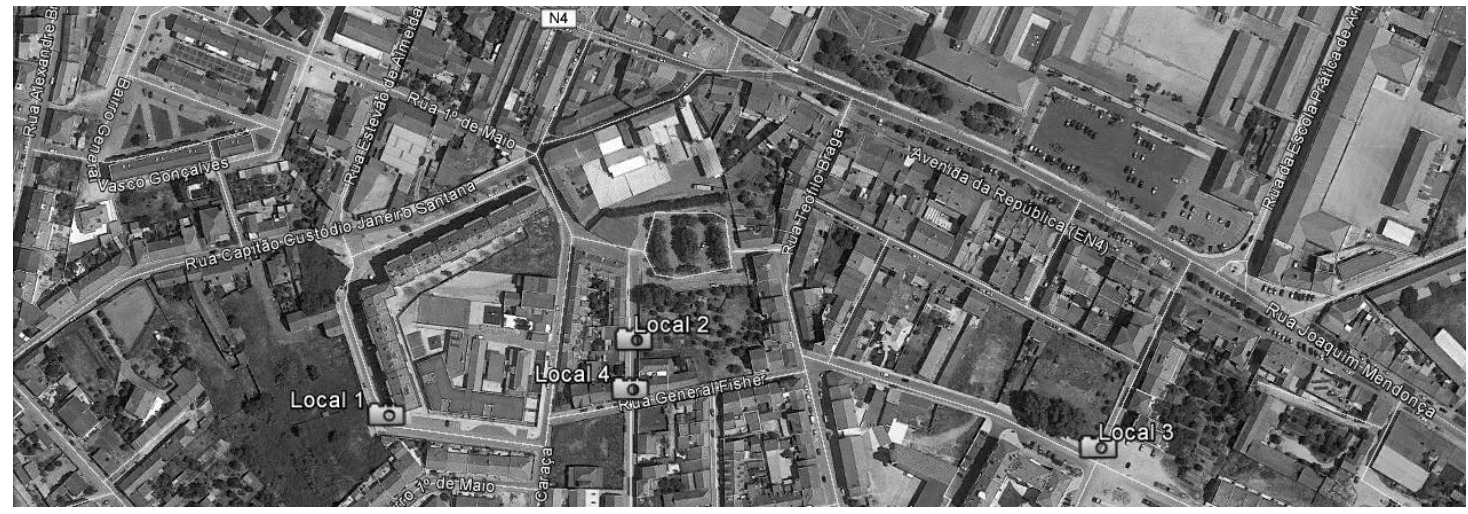

Fig. 9 - Planta de localização de "grandes espaços vazios expectantes" no perímetro urbano Fonte: Costa Lobo (1976)

\footnotetext{
${ }^{6}$ Com exceção da rede de água, que estava a ser projectada pelo então Gabinete de Apoio Técnico de Montemor-o-Novo, e previa já um crescimento significativo do aglomerado urbano.
} 


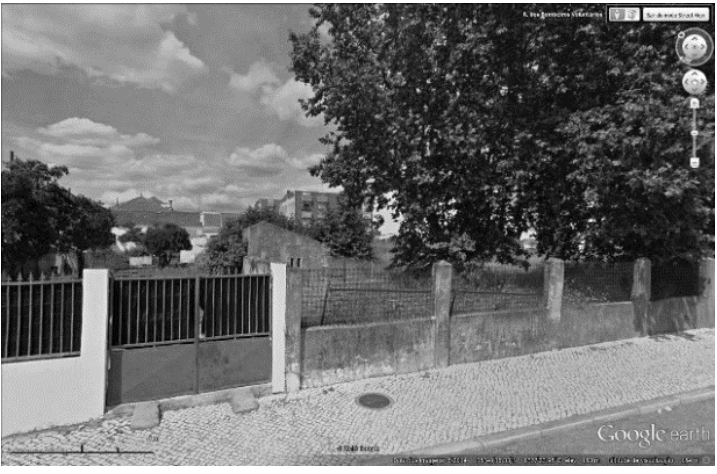

Fig. 10 - Vista do local 1

Fonte: Google Earth (2019)

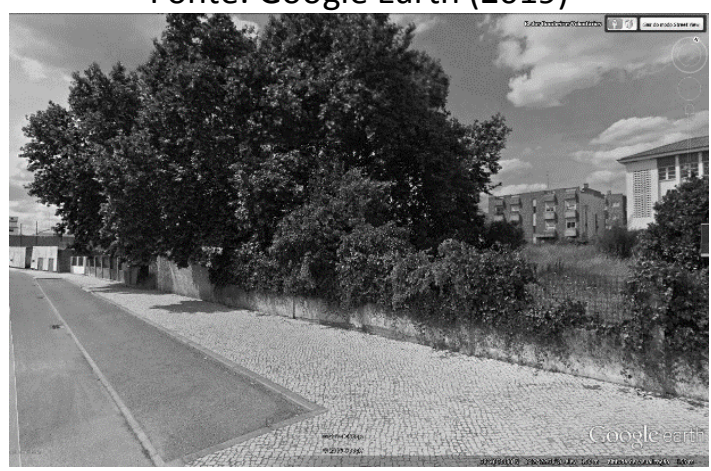

Fig. 12 - Vista do local 3

Fonte: Google Earth (2019)

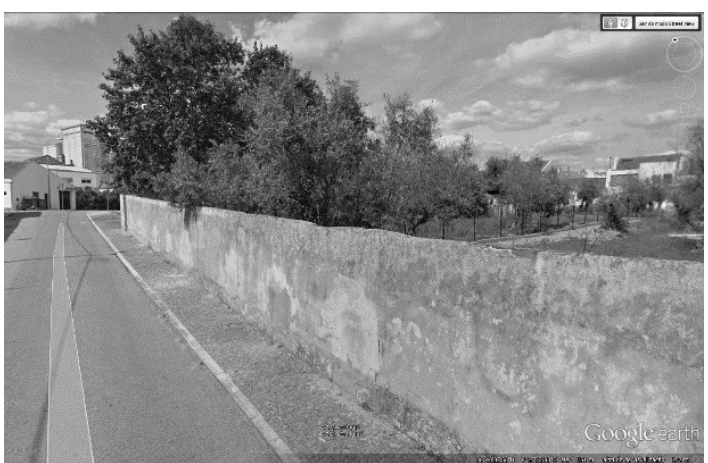

Fig. 11 - Vista do local 2

Fonte: Google Earth (2019)

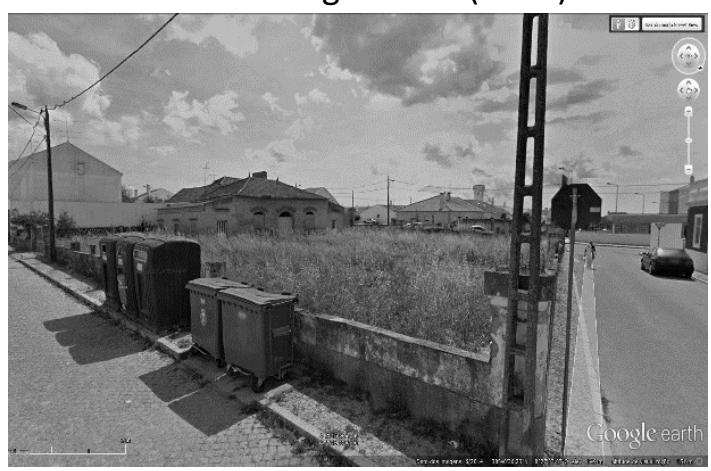

Fig. 13 - Vista do local 4

Fonte: Google Earth (2019)

No entanto, nem essa proximidade à área central, caracterizada por uma maior densidade da edificação e pela concentração dos estabelecimentos de comércio e serviços, impediu a existência de "grandes espaços vazios expectantes" na sua envolvente imediata.

Neste trabalho, considerou-se interessante abordar dois momentos do Plano, tirando partido do tempo decorrido e da possibilidade de se avaliar os dados então levantados, nomeadamente no que se refere à análise demográfica e à das infraestruturas de saneamento existentes no final da década de 1980.

De um ponto de vista metodológico, a análise demográfica constitui um elemento determinante na formulação dos cenários de desenvolvimento de Vendas Novas. O Plano aborda em primeiro lugar o problema da caracterização da população do concelho, com base em 4 aspetos considerados fundamentais: origem da população; distribuição espacial da população; composição etária; hipóteses de crescimento.

"Para qualquer destes aspetos, ... , servimo-nos dos resultados do inquérito à população e dos dados estatísticos editados pelo Instituto Nacional de Estatística." (Costa Lobo, 1976: p48). 


\section{1.o Método de estimação da população residente no concelho}

Considerando os dados demográficos relativos a cada aglomerado, estima-se a população em 1978, baseado num método que teve como ponto de partida o número de contadores elétricos domésticos (CE), que à época cobriam $87 \%$ dos alojamentos do concelho, e a dimensão média do agregado familiar (CDF), denominada "variável de trabalho definida como número de habitantes por contador elétrico".

Multiplicando o CDF pelo número de contadores elétricos de cada aglomerado populacional obteve-se uma estimativa da população residente em alojamentos com contador eléctrico, de 8.604 habitantes.

Considerando a taxa de cobertura dos CE (87\%) e aplicando o princípio da proporcionalidade, estimou-se a população do concelho em 9.890 habitantes.

\section{2.. Método de estimação da população residente no concelho}

Neste método foi considerado o recenseamento eleitoral e a população flutuante originada pelo quartel. Assim, considerando:

a - Recenseamento eleitoral de 1975 -> 8.589 eleitores

b - Pop. Quartel (flutuante) -> 1.100 hab

A população residente com idade superior a 18 anos, seria igual à diferença entre estes dois valores, isto é, de 7.489 habitantes.

Considerando a estrutura etária da população, obtida no inquérito à população, apurou-se que $73,7 \%$ da população tinha idade superior a 18 anos. Aplicando o complementar dessa taxa $(26,3 \%)$, correspondente à população com idade inferior a 18 anos, obteve-se uma estimativa da população residente no concelho de 10.160 habitantes.

A média dos valores dos dois métodos de estimação é de 10.025 habitantes, o que conduziu ao valor assumido de 10.000 habitantes para a população residente no concelho de Vendas Novas, para o ano de 1978.

\section{Modelos de projecção demográfica}

No que se refere às projecções demográficas, é salientado que nos modelos previsionais não causais se mantêm constante a tendência de evolução da população até ao horizonte 
temporal estabelecido. Já na utilização do modelo previsional causal, considerou-se como desejável a alteração da "macrocefalia da área metropolitana de Lisboa", sendo o seu peso demográfico a variável a alterar, de forma a ter "um efeito impulsivo que leva essas populações a emigrar". No entanto, por falta de dados estatísticos que pudessem ser utilizados neste tipo de modelos, não foi utilizado este método.

\section{Modelo não causal global}

Completando-se a série estatística obtida através dos Recenseamentos da População publicados pelo Instituto Nacional de Estatística (INE), com as estimativas obtidas com os dados dos Recenseamentos Eleitorais relativos ao ano de 1978, construiu-se o gráfico da evolução da população do concelho e estimou-se a população residente para um horizonte de 20 anos.

O coeficiente de correlação obtido para este modelo não causal foi de 0,864 , o que é um valor muito aceitável neste tipo de projecções, para mais quando se dispõe de uma série temporal tão longa.

Da aplicação do modelo para uma projeção a 20 anos, obteve-se uma estimativa para a população residente no concelho de cerca de 12.000 habitantes.

\section{2.․ Modelo não causal global}

Uma segunda estimativa para a população do concelho a 20 anos, utilizando o mesmo modelo global não causal, foi realizada sem considerar os valores recenseados para os anos de 1960 e 1970. Esta posição foi justificada pelo facto de se terem considerado que estes anos constituíram uma perturbação pontual no crescimento natural da população que se vinha observando desde a segunda metade do século XIX, e que terá a sua explicação na forte emigração que se verificou no concelho nessas duas décadas. As duas fábricas de montagem de automóveis que posteriormente se localizaram em Vendas Novas, vieram inverter esta tendência para a perda de população do concelho, como o confirmam os recenseamentos eleitorais após 1974.

A aplicação do modelo sem estes dois valores da população, conduziu ao gráfico da figura 14, atingindo-se agora um coeficiente de correlação de 0,955. No entanto, para uma 
projeção a 20 anos, a estimativa da população residente manteve o valor de 12.000 habitantes.

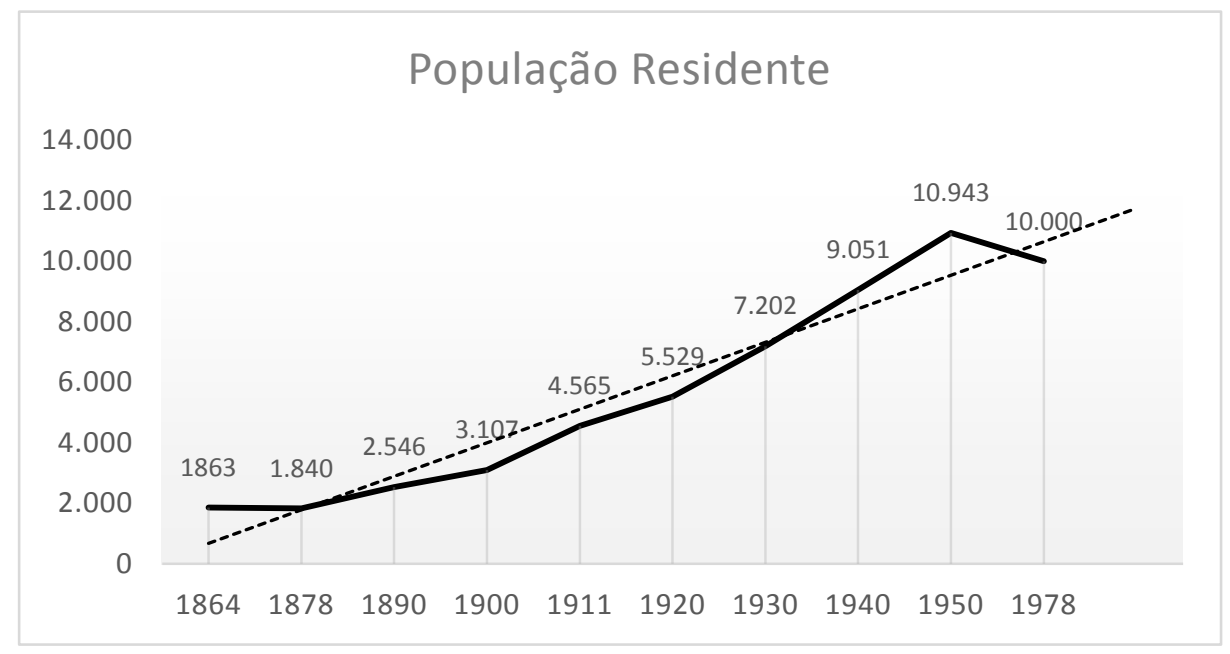

Fig. 14 - População residente no concelho de Vendas Novas - Modelo não causal global Fonte: Dados obtidos no Relatório de Análise do PGUVN (Costa Lobo, 1976).

\section{3.․ Modelo não causal global}

A aplicação do modelo Cohort Survival só foi possível com o recurso aos dados estatísticos para o distrito de Évora, no que se refere às taxas de natalidade e de mortalidade relativas a cada grupo etário, dado que essas taxas não eram publicadas por concelho.

Aplicando este modelo para uma projeção a 20 anos, obteve-se uma estimativa para a população residente igual a 10.106 habitantes.

Ou seja, assumindo que o saldo migratório fosse nulo, não existiria grande variação no crescimento populacional a 20 anos, em relação ao valor estimado para o ano de 1978.

Partindo das estimativas de evolução demográfica do PGUVN, vejamos qual foi a real evolução da população do concelho, registada nos dados censitários.

Da análise dos dados publicados pelo INE referentes à população residente no concelho de Vendas Novas, observa-se que não houve variação significativa da população nas últimas três décadas, traduzindo-se num acréscimo populacional de apenas 913 pessoas, valor sensivelmente igual a metade do acréscimo demográfico previsto no PGUVN. O encerramento das fábricas de montagem de automóveis nos anos 1980 e a redução dos efectivos militares na Escola Prática de Artilharia, na sequência do fim da guerra colonial e da reestruturação do Exército que se Ihe seguiu, terão sem dúvida contribuído para este 
abrandamento do crescimento demográfico no concelho. A continuação da atracção migratória exercida pela Área Metropolitana de Lisboa, ao contrário do que se pretendia nos Planos de Fomento e no cenário regional adoptado pelo PGUVN, foi outro importante factor explicativo para este facto.

\section{Análise das infraestruturas de águas e esgotos}

- Sistema de saneamento

À data do PGUVN, o sistema de esgotos de Vendas Novas era composto por duas redes de coletores, compreendendo 8 zonas de drenagem (sub-redes), um emissário e uma estação de tratamento. A Rede A de colectores servia o núcleo mais antigo, enquanto a Rede B servia a zona de transição para os foros.

A rede A era composta pela agregação das sub-redes 1-2-7-8, com capacidade para 6.900 habitantes, servindo então apenas 3.200 habitantes. Por sua vez, a rede B era composta pela agregação das sub-redes 3-4-5-6, com capacidade para 4.000 hab., servindo na altura apenas 1.900 habitantes (Fig. 15).

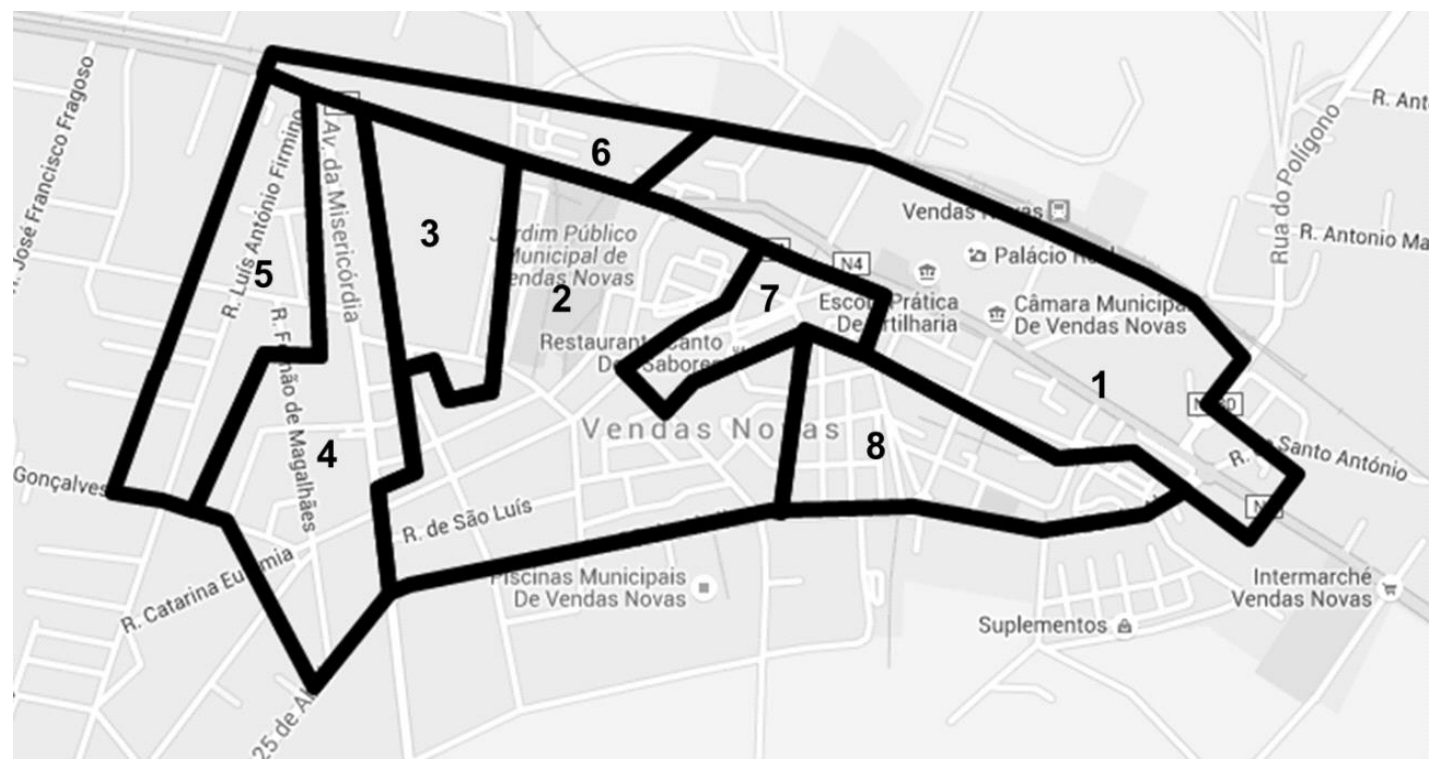

Fig. 15 - Planta com localização das redes de esgotos e das respetivas zonas de drenagem no aglomerado de Vendas Novas

Fonte: Costa Lobo, 1976

O emissário, à data em fase de conclusão de obra, tinha capacidade de transporte para 22.400 habitantes. No entanto, após a sua ligação, a população servida foi apenas de 5.000 habitantes. 
A estação de tratamento, igualmente em construção à data de elaboração do PGUVN, foi projectada para 12.000 habitantes.

A análise do sistema de saneamento básico (redes de esgotos domésticos, emissário e estação de tratamento de águas residuais) foi ainda desenvolvida através de uma metodologia inovadora, que terá sido aplicada pela primeira vez no país. A "análise de limiares", metodologia elaborada por Boleslaw Malisz nos anos 1960 (Malisz, 1962 e 1972) para apoiar o planeamento urbano e regional na Polónia - nomeadamente na construção de cidades novas - permite definir os limites de capacidade de cada uma das componentes do sistema de saneamento e, a partir daí, identificar quais as áreas que apresentam maior capacidade para absorver o crescimento urbano sem aumento de custos concentrados de infraestruturação. A figura 16 apresenta a sistematização dos resultados desta análise elaborada para fundamentar a escolha das áreas de densificação urbana em Vendas Novas.

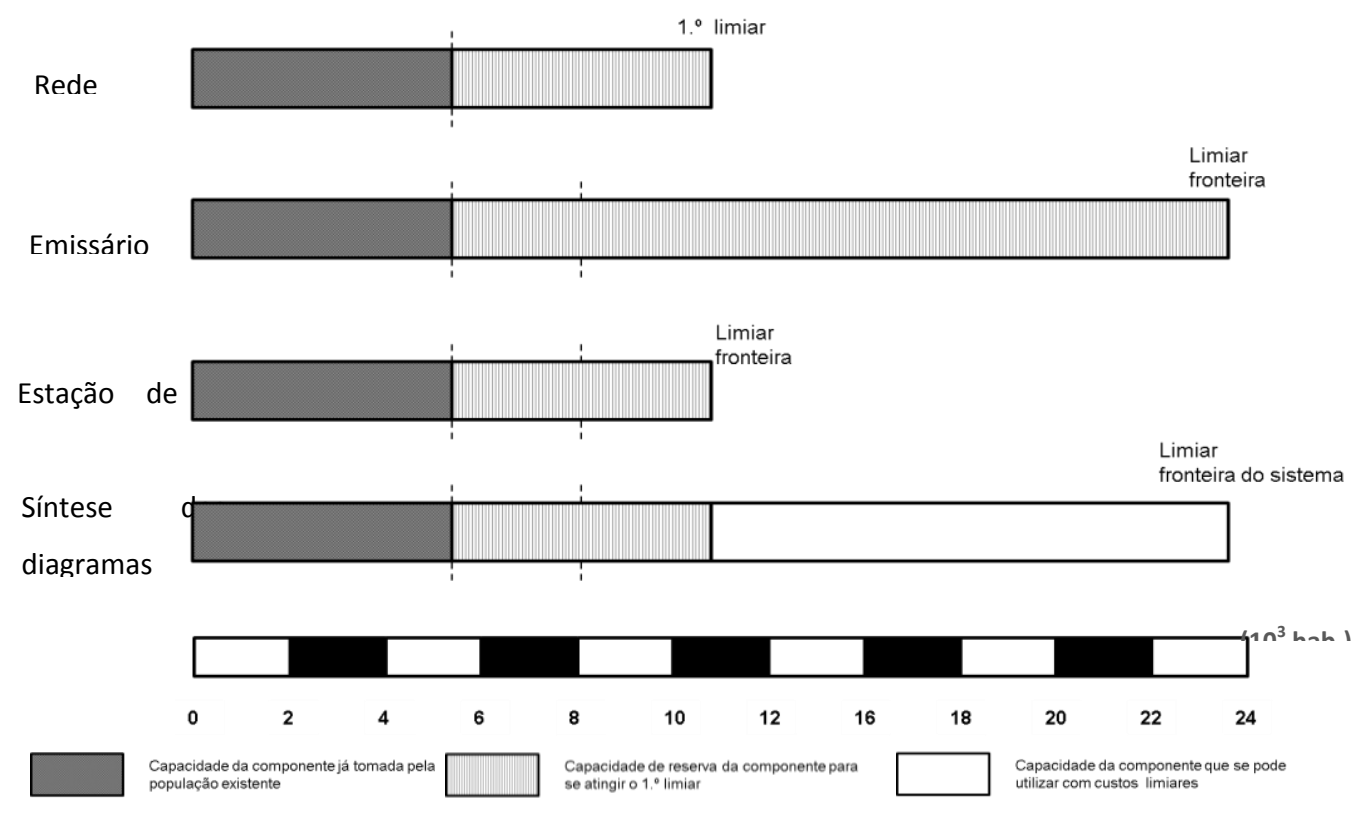

Fig. 16 - Diagrama de capacidades do sistema de saneamento Fonte: Adaptado de Malisz (1962 e 1972)

\section{Limiar e limiar fronteira das componentes do sistema de esgotos domésticos}

O diagrama de capacidades demonstra, tal como é referido no texto do relatório de Análise, que seria necessário efetuar novos investimentos em infraestruturas, nomeadamente na expansão da capacidade da rede de esgotos e no aumento de capacidade da estação de tratamento. Tal situação ficaria a dever-se ao facto de se prever a ligação da rede de 
esgotos domésticos aos Foros da Misericórdia e ao Quartel, o que colocaria o sistema perto do seu 1. limiar. Por outro lado, a estação de tratamento, com um limiar nos 11.000 habitantes, não suportaria a população prevista a 20 anos (12 mil habitantes), ainda que na altura só estivesse a servir uma população de 8.000 habitantes.

- Sistema de abastecimento de água

O sistema de abastecimento de água de Vendas Novas era composto, à data do PGUVN, pelo sistema adutor, os reservatórios e pela rede de distribuição.

O sistema adutor estava dimensionado para um limiar de 19.000 habitantes, enquanto que a rede de distribuição, caracterizada como sendo malhada, apresentava uma capacidade de abastecimento para 11.500 habitantes.

Os reservatórios então existentes tinham uma capacidade para $1.000 \mathrm{~m}^{3} \mathrm{e}$, segundo o Relatório de Análise, "ainda não se terá atingido o limite das reservas disponíveis".

Adutora

Reservatórios

Rede de distribuição

Síntese dos diagramas parciais
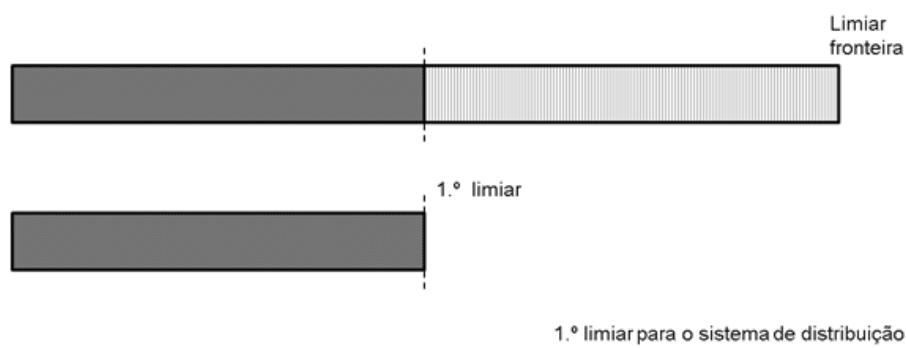
existente $\left(2{ }^{\circ}\right.$ depósito)
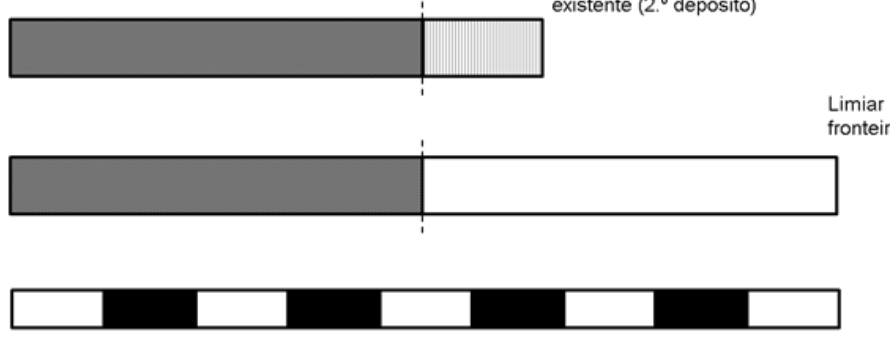

(10 $0^{3}$ hab.)

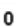

2

\begin{tabular}{l|l|l}
4 & 6
\end{tabular}

10

\begin{tabular}{l|l|l|l|}
12 & 16 & 18 & 20
\end{tabular}

Capacidade da componentejá tomada pela populaçăo existente

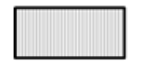

Capacidade de reserva da componente

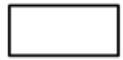

Capacidade da componente que se pode utilizar com custos limiares (construção de um ou mais reservatórios)

Fig. 17 - Diagrama de capacidades do sistema de abastecimento de água Fonte: Adaptado de Malisz (1962 e 1972)

Do diagrama de capacidades das componentes do sistema de abastecimento de água (Fig. 17) importa realçar a debilidade que o sistema apresentava, nomeadamente no que se referia à falta de capacidade dos reservatórios face a eventuais necessidades pontuais, visto 
que os reservatórios "ainda chegavam para satisfazer a atual população, não considerando os casos de eventuais emergências nem a existência de consumos pontuais devidos ao Quartel e diversas unidades industriais." (Costa Lobo, 1976: p51)

A proposta final de zonamento do PGUVN, resultou assim do cruzamento da leitura do território efetuada pela equipa (em particular no que se refere às suas formas de ocupação e uso do solo, e à sua evolução recente) com a capacidade instalada, existente e prevista, da sua rede de infraestruturas urbanas.

\subsection{A Proposta}

Tal como seria de esperar, a proposta vem consubstanciar as orientações e consolidar algumas tendências enunciadas na fase de análise.

No ponto respeitante ao Enquadramento Regional, mantiveram-se as mesmas premissas, embora estas privilegiem agora, ainda que ligeiramente, a Área Metropolitana de Lisboa enquanto possível centro polarizador da vila de Vendas Novas, em detrimento do alargamento da área de influência de Évora na estruturação deste território.

Por outro lado, continuou a apostar-se no eixo Vendas Novas/Pegões, posição aparentemente suportada na rede viária de ligação entre estas duas localidades, resultando hoje um pouco difícil compreender as razões que fundamentaram esta firme convicção dos autores do Plano, tendo em conta os elementos disponíveis que se puderam consultar.

O grau de certeza relativamente à exequibilidade e vantagens deste cenário era tão forte que, na memória descritiva do Plano, se propõe o repensar do ordenamento administrativo dos limites do concelho, afirmação reiteradamente repetida no texto da memória descritiva da Proposta.

Mas é a proposta de zonamento para o núcleo urbano de Vendas Novas, que ocupa a maior parte da memória descritiva, desenvolvendo uma explicação detalhada das opções tomadas.

Tomando como referência um cenário de crescimento muito defensivo - cerca de mais 1.000 habitantes até ao ano 2000 - a solução aponta, aliás muito compreensivelmente, para 
um preenchimento das áreas expectantes dentro do perímetro urbano, já então servidas pelas infraestruturas urbanísticas.

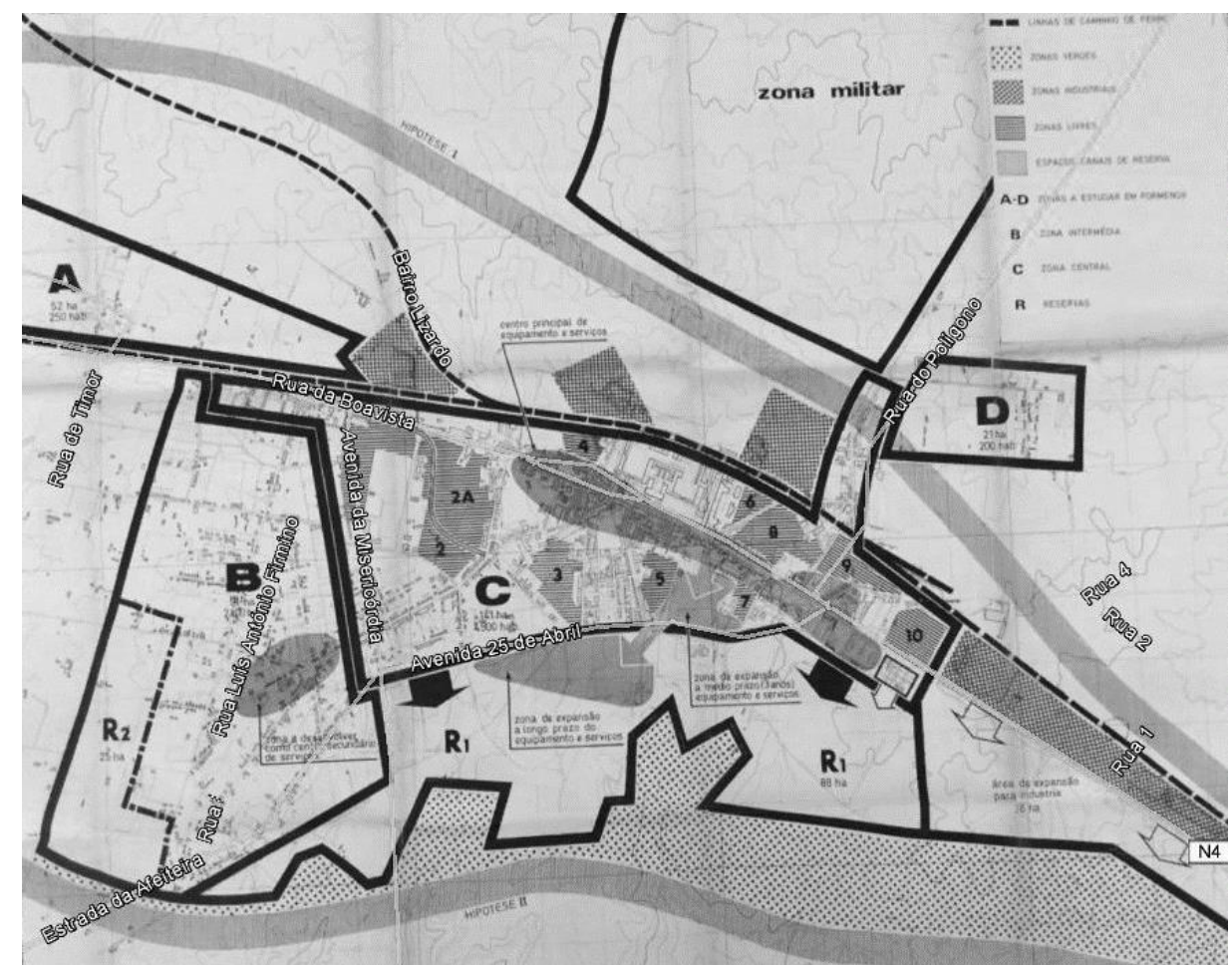

Fig. 18 - Planta de Zonamento do PGUVN: A e D - Zonas a estudar em pormenor; B - Zona Intermédia; C - Zona Central; R - Zonas de Expansão e Reservas Fonte: PGUVN (Costa Lobo, 1976)

Mais concretamente, esta opção dirige-se à área central do aglomerado (Zona C), onde, para uma área de 141 ha, a equipa estimava uma população residente de cerca de 4.500 habitantes, o que significava que se estaria em presença de uma densidade populacional bruta modesta - de apenas 32 hab/ha - inferior por isso aos 100 hab/ha usuais em espaços urbanos centrais mais consolidados, observáveis em cidades de pequena dimensão (Fig. 18). Face a esta situação, o Plano propunha a densificação desta zona central, através de um aumento da densidade populacional para 120 hab/ha, tirando partido da localização do principal eixo de equipamentos ao longo da EN4, o qual teria, neste cenário de desenvolvimento urbanístico, a hipótese de se desenvolver para sul, ao integrar as zonas de expansão habitacional propostas. Tal resultaria num crescimento populacional de 13.000 habitantes, atingindo-se um total de 17.500 habitantes.

A outra zona a densificar considerada foi a intermédia (Zona B), que se constituiria como um espaço de transição entre a "Zona Central" e a "Zona Rural". Também para aqui se 
propunha uma densificação, dado que se tratava de uma área com 91 ha e uma densidade populacional bruta de 26 hab/ha, tendo por isso uma evidente capacidade de acomodar o dobro dos seus habitantes. Ou seja, num segundo momento, e a confirmar-se a tendência de crescimento prevista, seriam ocupadas as zonas "adjacentes ao perímetro urbano e já comprometidas com construção e, nalguns casos, já totalmente infraestruturadas" (Costa Lobo, 1976: p21).

Continuando a percorrer a legenda da Planta de Zonamento, assinalam-se as "Zonas a Estudar em Pormenor", todas elas implantadas a norte da via-férrea e, como tal, com pouca ou nenhuma viabilidade de desenvolvimento devido à sua localização excêntrica em relação ao centro e separada deste pela barreira física constituída pelo feixe de linhas da estação ferroviária e pelas instalações da Escola Prática de Artilharia.

Para as "Zonas Industriais", na altura com cerca de 33 ha, sugeria-se uma maior diversificação, tendo em conta que Vendas Novas estava então muito focada na indústria automóvel, sector que já evidenciava sinais de crise e que culminou com o encerramento das fábricas de montagem de automóveis nos anos 1980.

No espaço urbano são ainda identificadas as "Zonas de Expansão e Reservas", estas últimas constituídas por espaços canais afetos às hipóteses de alternativa à EN4, e às zonas destinadas a equipamentos, habitação e indústria. Apesar desta possibilidade, conferida pelos terrenos disponíveis, o PGU não considerava o preenchimento destas áreas, mesmo no cenário demográfico mais otimista, que previa a possibilidade de a população de Vendas Novas poder vir a atingir os 23.000 habitantes.

Por fim, a "Zona Rural", onde a proposta era, naturalmente, o da sua manutenção.

\subsection{Uma leitura da Proposta (1978-2016)}

Seria de esperar que um trabalho realizado na então Universidade Técnica de Lisboa (UTL) e no Centro de Sistemas Urbanos e Regionais (CESUR) ${ }^{7}$ integrasse igualmente uma abordagem teórica desse mesmo estudo, recorrendo aos instrumentos de análise permitidos pela diferença temporal entre os dois trabalhos. Deste modo, ir-se-á tentar, assumindo as

\footnotetext{
${ }^{7}$ O CESUR foi o primeiro centro de investigação multidisciplinar da então UTL, agregando académicos do IST, ISEG e ISA. Foi fundado em 1976 pelos Professores Costa Lobo e Simões Lopes.
} 
dificuldades inerentes a um trabalho deste tipo, esboçar uma leitura do modelo de intervenção territorial proposto em 1980 pela equipa coordenada pelo Prof. Costa Lobo.

Obviamente que este estudo não constitui um ensaio, "não só exige destreza intelectual mas também limpidez explanativa" (Vieira de Almeida, 1962) ${ }^{8}$, antes constitui, tão só, uma análise técnica de uma proposta urbanística perfeitamente contextualizada, num momento muito particular da nossa história recente: os anos imediatos ao 25 de Abril, caracterizados por uma permanente atitude de desafio intelectual.

É neste quadro que, o que hoje seria de certa forma inaceitável numa proposta de uso do solo constante de um instrumento formal de gestão urbanística, dada a imprecisão dos limites do zonamento proposto, torna-se compreensível à luz da instabilidade socioeconómica que o país vivia naqueles anos.

Por outro lado, o conceito de ordenamento do território, introduzido pelo III Plano de Fomento (1969/73) enquanto preocupação determinante a considerar no modelo de desenvolvimento nacional, dava ainda os seus primeiros passos, gerando, por esse motivo, alguma ambiguidade na abordagem destes instrumentos de planeamento. No presente caso, esse facto irá refletir-se na proposta final de zonamento, apesar de esta se fundamentar num modelo clássico de levantamento, análise e diagnóstico do território.

No entanto, se analisarmos a representação dos diferentes tipos de espaço considerados na planta de zonamento, verificamos alguma coerência com a discussão em torno do conceito de espaço, sobre a qual se debruçaram vários autores de referência, como Bruno Zevi, Sigfried Giedion, Giulio Carlo Argan e Kevin Lynch.

"É curioso notar que todas as investigações sobre o espaço e sobre o processo de o dominar, se referem ao espaço exterior" (Vieira de Almeida, 1962). Ainda segundo Pedro Vieira de Almeida, no seu "Ensaio sobre o Espaço da Arquitetura", "a diferença fundamental apontada por Kevin Lynch e Erdsiek também, entre o espaço urbano e o espaço arquitetónico, é a noção de tempo. (...) Lynch, ao referir-se ao tempo biológico da cidade, separa definitivamente a atividade do urbanista e do arquiteto" (Vieira de Almeida, 1962).

Também os conceitos de "Espaço de Transição" e de "Espaço Ambíguo", apesar de abordados numa perspetiva de espaço arquitetónico ou pictórico (ambíguo), dão alguma

\footnotetext{
${ }^{8}$ Tese para obtenção do Diploma de Arquitecto.
} 
coerência ao grafismo utilizado no Plano, se bem que se constate que esta situação se apresenta como uma linguagem mais interiorizada que intencional.

Se por um lado "o espaço de transição só encontra verdadeira justificação através de uma maior e mais profunda noção de espaço interno e externo", o espaço ambíguo, segundo José Augusto França, "vai realizar-se inteiramente em contacto com as formas, mas não por contradição, como se poderia supor, lembrando a dialética das relações clássicas. Vai realizar-se por expansão. Ele vai não absorver as formas, mas absorver-se nelas, fundindo-as de modo a criar o que se pode chamar um espaço forma..." (França, 1987).

Esta tese, apesar de a considerarmos como uma razão a posteriori e não a anteriori, como seria desejável, vem fundamentar a ambiguidade dos espaços constantes na Planta de Zonamento, quer no que se refere ao uso do solo, quer no que diz respeito à sua definição.

Mas, tal como afirmou José Augusto França, quando se referia a estes espaços num contexto estritamente pictórico, estes não absorveram as formas, mas fundiram-se com elas, através do preenchimento dos espaços vazios.

Na realidade, a ambiguidade do Plano mais não era que um processo intencional de apontar tendências preferenciais de ocupação do uso do solo, essas sim, baseadas tecnicamente nas análises sectoriais realizadas.

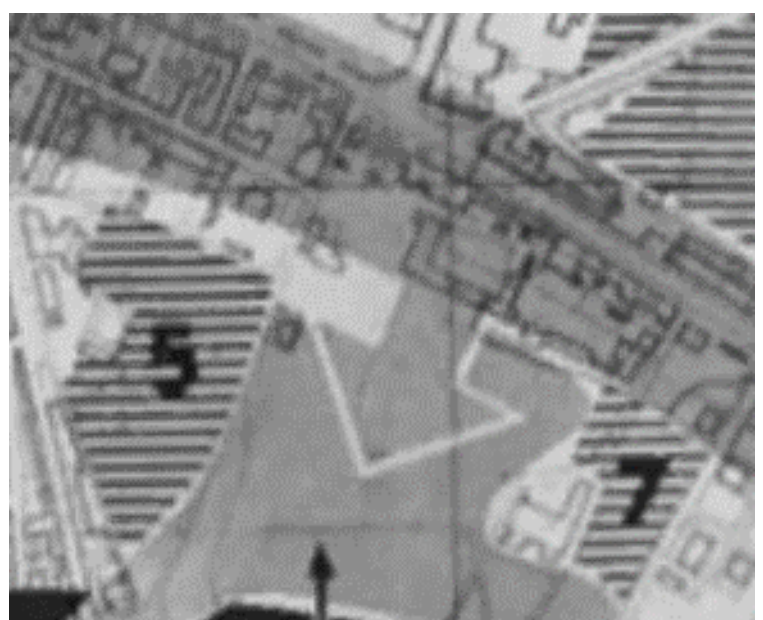

Fig. 19 - Planta de Zonamento do PGUVN Espaços ambíguos (1978) Fonte: Costa Lobo (1980)

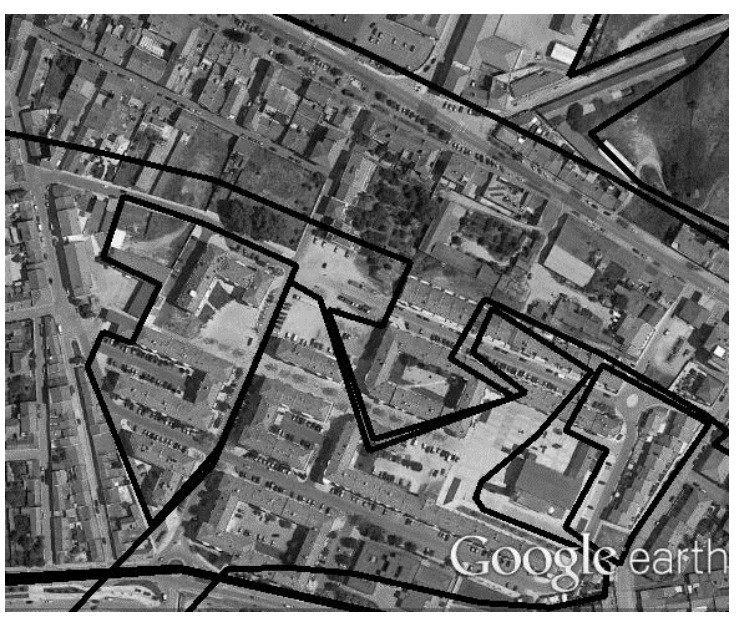

Fig. 20 - Planta de ocupação do solo - Espaços ambíguos do PGUVN (2016) Fonte: Google Earth (2016)

Também a proposta de regulamento urbanístico do Plano segue este princípio, ao recorrer a um texto que confere um razoável grau de liberdade na utilização dos índices apontados. 
O Plano concretizou-se ao longo do tempo enquanto instrumento de gestão territorial de referência, já que nunca foi eficaz juridicamente ao não ser objecto de aprovação por parte do Governo. Contudo, os 36 anos que nos separam da sua elaboração, demonstram que o seu contributo foi efectivo e positivo para o desenvolvimento urbano de Vendas Novas,

Foi esta inovação e equilíbrio conceptual, presentes em toda a elaboração deste PGU, que procuramos realçar nesta análise.

Face ao anteriormente exposto, para que essa concretização positiva do Plano viesse a verificar-se, houve que ultrapassar o mero entendimento teórico e formal do planeamento urbano, ancorando-se antes a intervenção no espaço urbano existente, num profundo conhecimento dos processos de formação do território e de alteração dos usos do solo, conhecimento esse baseado num modelo científico de análise, diagnóstico e proposta.

Outro aspecto que importa realçar, pelo que representou de antevisão face ao que a posterior legislação urbanística veio a consagrar quase 20 anos depois, sob a designação de UOPG (Unidade Operativa de Planeamento e Gestão), foi a divisão do espaço urbano em sub-espaços de características homogéneas ou singulares, para os quais se definiam objectivos urbanísticos, programas de intervenção ou até se apontavam referências que ilustrassem o espaço a urbanizar e edificar.

\section{A concretização no terreno: o tempo biológico do urbanismo}

Sendo certo que o Plano aponta os eixos de desenvolvimento do território contido no perímetro do PGUVN (mais tarde melhor expressas no PDM de Vendas Novas, de 1999), as intenções de intervenção urbanística foram-se objectivando e concretizando ao longo do tempo, segundo aqueles instrumentos de gestão territorial.

Uma abordagem quantitativa da concretização do PGUVN, tentando isolar as operações dele decorrentes, revela que o Plano teve, no período de 19 anos, uma significativa concretização, sendo que $1 / 3$ da área urbanizada foi de iniciativa municipal. Todavia, quando se contabiliza a área efectivamente urbanizada por contraposição a todo o perímetro urbano proposto, incluindo as designadas "Áreas de Reserva", verifica-se que esta não excede os $10 \%$. 
Esta situação não nos surpreende, dado que, com a falência do modelo de desenvolvimento económico previsto, coube à autarquia o principal papel de agente dinamizador da economia local, assegurando a concretização dos usos do solo necessários à qualidade de vida dos seus munícipes, processo que se inicia em 1978/80 com o PGUVN.

Das várias propostas concretizadas no terreno, merecem destaque as que seguidamente se apresentam (Fig. 21).

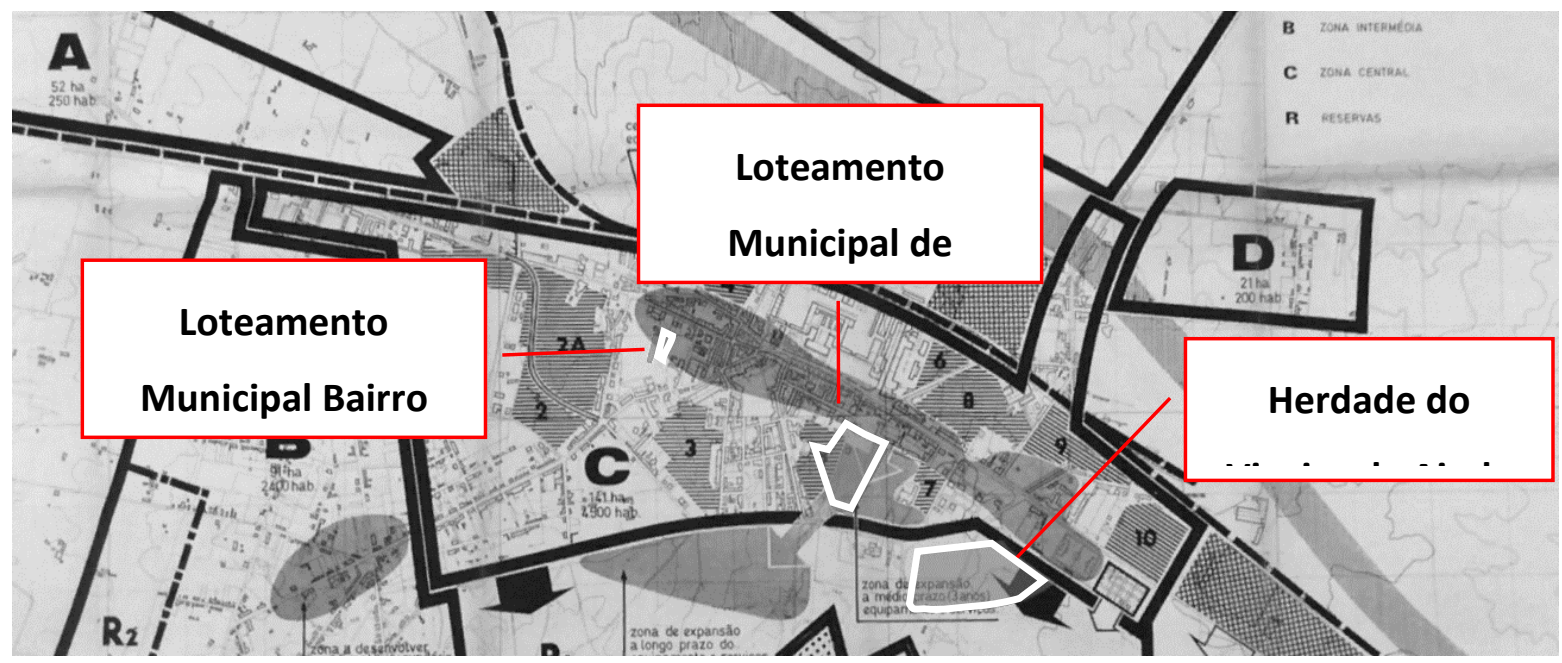

Fig. 21 - Planta de localização das intervenções na área urbana mais consolidada do PGUVN Fonte: Costa Lobo (1980)

Herdade do Viveiro da Ajuda (IISED ${ }^{9}$, 1982)

De acordo com a memória descritiva do Estudo Prévio que justifica esta intervenção, procurou-se "contribuir para uma solução equilibrada das negociações em curso entre a C.M. de Vendas Novas e um proprietário privado de uma parcela de terreno situado na vila, no sentido de libertar área vocacionada para a instalação de equipamento escolar e desportivo (cerca de 7,5 ha) e abrir uma frente de construção para habitação (cerca de 4,5 ha), dando assim resposta a dois tipos de carências sentidas pela população do concelho".

Este estudo prévio possuía a singularidade de, para além de apresentar uma solução urbanística para a área residencial, "sugerir também uma metodologia a seguir nas negociações entre a C.M. de Vendas Novas e o Proprietário". Este aspeto merece referência

\footnotetext{
${ }^{9} \mathrm{O}$ IISED foi uma entidade que substituiu transitoriamente o CESUR devido a um novo enquadramento legal dos centros de investigação da UTL, que entretando foi revogado, retomando o CESUR as suas anteriores funções e capacidades de prestação de serviços à comunidade.
} 
porque estamos em presença de um trabalho que não se esgota na proposta de desenho urbano, antes propõe um modelo de gestão do território.

Na realidade, não se pode dissociar este estudo prévio do próprio PGU que, para além do desenho urbano, explicitou um conjunto de conceitos de ordenamento e de gestão urbana, que se refletiram posteriormente nos instrumentos de iniciativa municipal que se lhe seguiram. Com efeito, segundo os autores do trabalho, a solução proposta para a ocupação urbana dos 4,65 ha baseia-se em premissas que podemos encontrar já referenciadas no PGU e que se vão refletir no desenho urbano proposto, entretanto concretizado (Fig. 21).
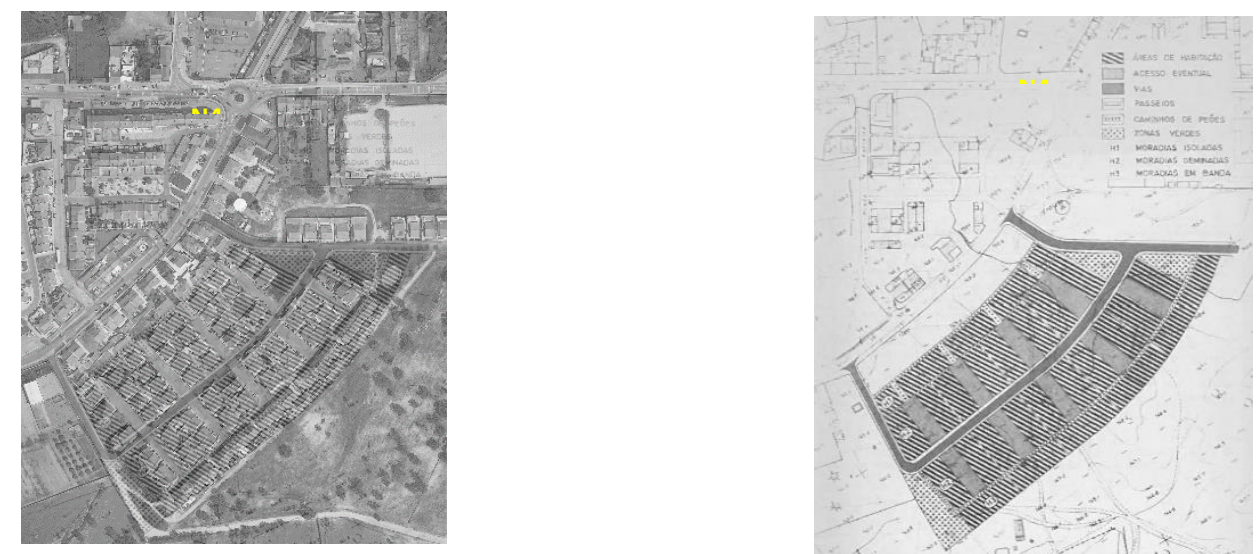

Fig. 22 - Herdade do Viveiro da Ajuda. Planta da proposta de intervenção e tecido urbano construído Fonte: Costa Lobo (1980)

Deste estudo prévio, retira-se igualmente o quadro das características dos lotes e a sua ocupação por tipo, verificando a sua analogia com o quadro existente no PGUVN.

A elaboração desta proposta de loteamento veio permitir esclarecer um aspeto particularmente importante - e muitas vezes ignorado no planeamento urbano - que poderemos designar por reflexo metodológico, isto é, algo que se explicita em instrumentos de gestão territorial que não definem o desenho urbano, mas que tem como base um estudo de pormenor concretizado a montante, onde esse desenho já se antevê.

\section{Loteamento Municipal de Vendas Novas (CESUR)}

Elaborado no CESUR, que entretanto passou a assessorar a CMVN na implementação do PGU, este projeto de loteamento municipal concretizava o programa de desenvolvimento 
do município de Vendas Novas, proposto no PGU e posteriormente reafirmado no Plano Diretor Municipal de 1999.

Tendo a Câmara Municipal como entidade promotora, o programa deste projeto de loteamento, pretendia alcançar os seguintes objetivos:

1. Solução que promova o alargamento e a modernização do centro funcional de Vendas Novas, integrando um conjunto de equipamentos, como o mercado municipal, os serviços de Registos e Notariado e de Finanças.

2. Tipologias de fogos com predominância de T3 e T2.

3. Fogos de dimensão superior às dimensões mínimas previstas na lei.

4. Solução de desenho urbano compatível com a centralidade urbana da área de intervenção.

Conforme se pode verificar, o grau de concretização deste loteamento aproxima-se muito, ou atinge mesmo, os $100 \%$, mais uma vez segundo a localização inicialmente prevista no PGUVN (Fig. 22).
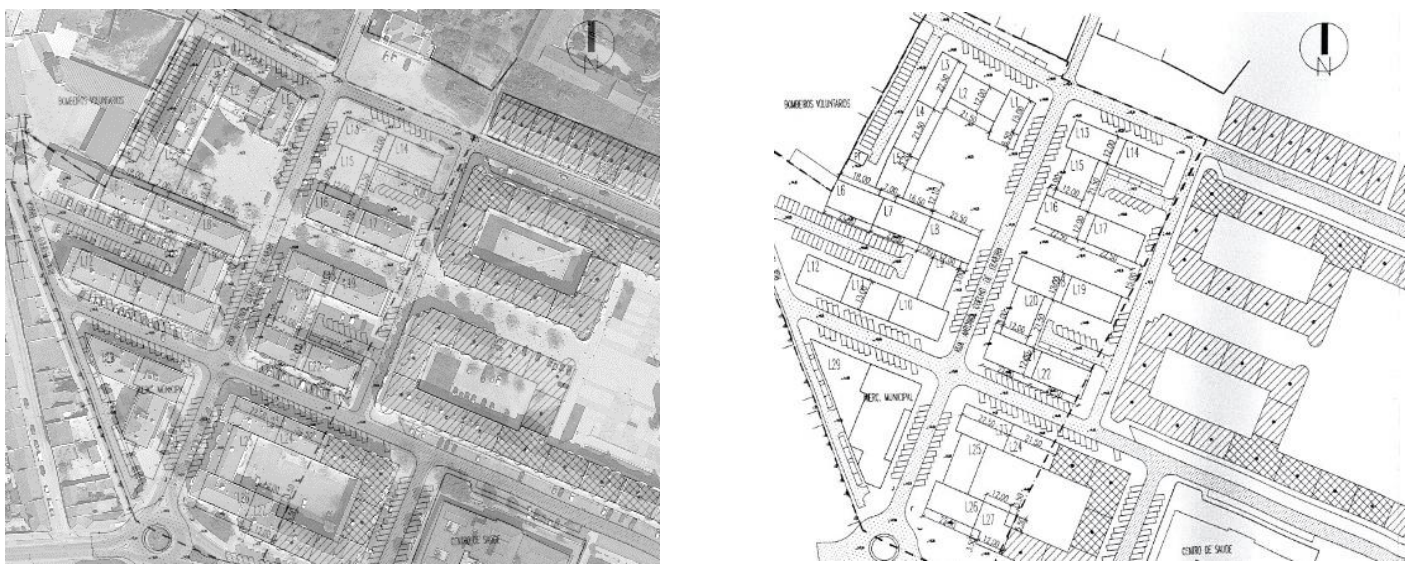

Fig. 23 - Planta com a localização face ao PGU e desenho urbano da proposta do loteamento Fonte: Costa Lobo (1980)

\section{Loteamento Municipal Bairro General Vasco Gonçalves (1995)}

Este loteamento, também de iniciativa municipal, foi desenvolvido pelos serviços técnicos da CMVN em colaboração com o CESUR, num terreno da posse do município, onde se previa inicialmente um Contrato de Desenvolvimento de Habitação (CDH), à época da responsabilidade do então Fundo de Fomento de Habitação (FFH).

Contudo, esta operação nunca chegou a ser iniciada pelo FFH, apesar dos projetos terem sido aprovados pela CMVN. Face à situação criada, a Câmara Municipal tomou a iniciativa de realizar este projeto destinado a habitação social, assumindo as suas obrigações contratuais 
com o IGAPHE, organismo para o qual foram transferidas algumas das antigas atribuições do FFH, após a sua extinção em 1982.

Estamos, portanto, a intervir mais uma vez numa área urbana consolidada da Vila, detentora das infraestruturas urbanísticas necessárias, concretizando no terreno, o processo de urbanização e edificação proposto no PGU. De facto, esta vem completar a Urbanização do Bairro Vasco Gonçalves, cuja primeira fase havia sido concluída, permitindo agora concretizar mais oferta de habitação social e a instalação de alguns equipamentos colectivos, de que se destaca o novo mercado municipal.

Tendo em conta a documentação existente no CESUR relativamente a este processo, é curioso observar que administração central, neste caso a Comissão de Coordenação Regional do Alentejo (CCR Alentejo), manifestou algumas reservas quanto ao facto de se poder considerar o terreno como urbano, uma vez que não existia um PMOT eficaz, o que motivou um fundamentado parecer do CESUR, em agosto de 1995, que vem justificar o caracter urbano da iniciativa do município.

Interessa reter ainda para a compreensão deste caso, o enquadramento jurídico existente (Decreto-Lei n.o 448/91) que surge com a revogação do anterior Decreto-Lei n.o 400/84, de 31 de dezembro, e que serviu de base ao contraditório elaborado pelo CESUR junto da CCR Alentejo $^{10}$.

Ultrapassada que foi esta fase de aprovação, concretiza-se então no terreno esta fase final do Bairro Vasco Gonçalves, constituída por 5 lotes e 30 fogos.

Outro aspecto que interessa analisar no tocante à concretização do PGUVN, tem a ver com a sua conformidade com as disposições posteriores do PDM. Na figura seguinte estão sobrepostos os tipos de usos previstos no PDM de 1990 sobre a planta do PGU.

Da análise da Fig. 23 podem retirar-se as seguintes conclusões:

- Quanto às áreas a estudar (Zona A e D), percebe-se que houve a intenção de promover a expansão urbana para essas áreas, mas com a preocupação de proteção da estrutura verde existente.

- As zonas de reserva não tiveram qualquer influência na definição dos usos do solo, visto a zona R1 ter ficado parcialmente afeta a espaços urbanizáveis (cerca de 6 ha), quando

\footnotetext{
${ }^{10}$ As CCR eram (e são, com a designação de CCDR) órgãos desconcentrados do Estado que tinham competências no domínio do planeamento territorial, nomeadamente na apreciação dos planos municipais.
} 
estavam previstos no PGU cerca de 98,5 ha. Por sua vez, a zona de reserva R2 ficou totalmente classificada como espaço urbano, não tendo no entanto sido urbanizada.

- Em relação às zonas industriais, é claro que a estratégia do PDM não era a mesma preconizada no PGU, pois definiu a expansão para a zona norte do eixo viário e da zona industrial consolidada, ao invés do previsto no PGU, que indicava a expansão da zona industrial para sul da zona já consolidada.

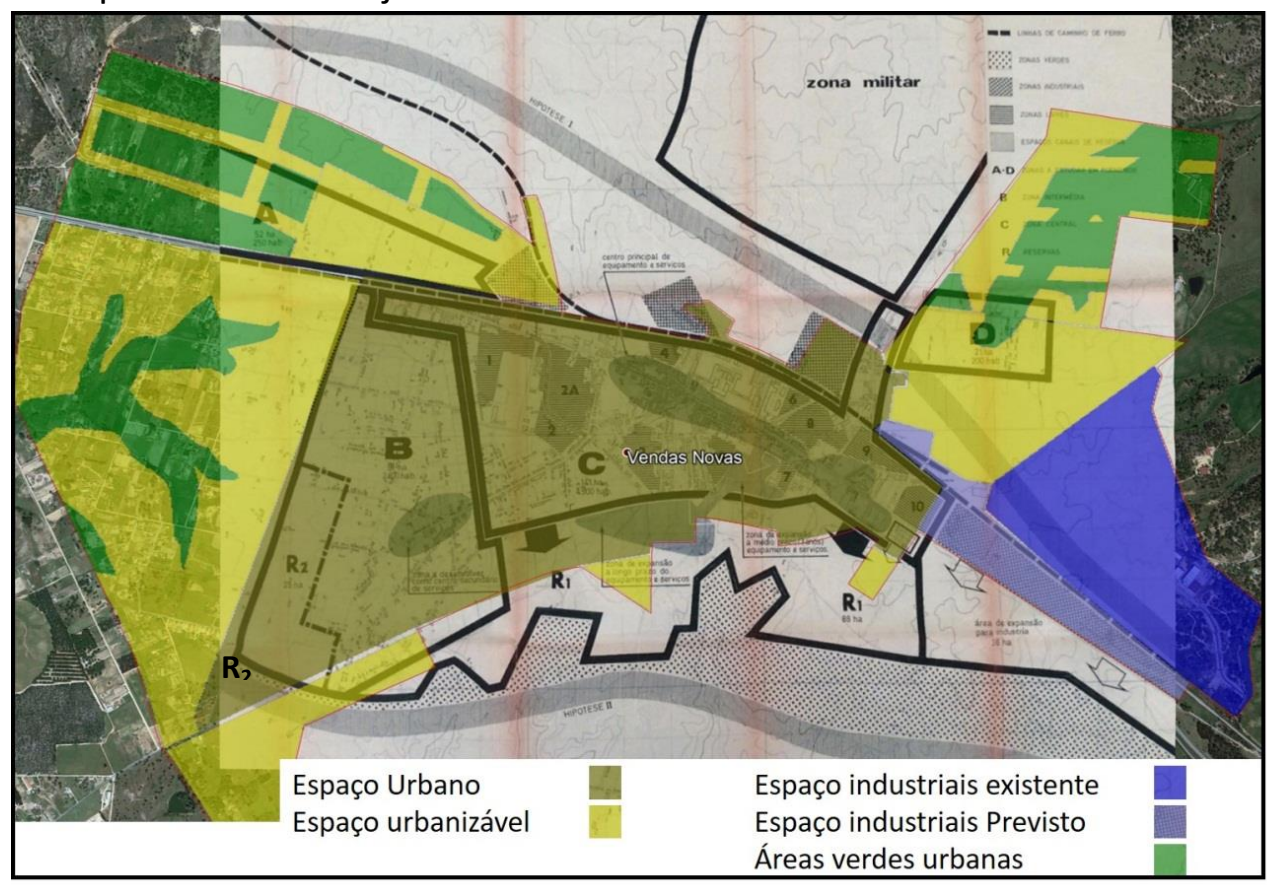

Fig. 24 - Sobreposição dos usos do solo previstos no PDM e no PGU de Vendas Novas Fonte: Costa Lobo (1980)

No que se refere às zonas de expansão definidas no PGUVN, verifica-se que houve uma concretização de $100 \%$ no tocante à zona de expansão a longo prazo de equipamentos e serviços. Houve aliás um aproveitamento das zonas contíguas à inicialmente prevista, aumentando a área destinada a estes usos para 18 ha, quando no Plano estavam unicamente previstos 9 ha.

Quanto à zona de expansão prevista no Plano para desenvolver um centro secundário de serviços que apoiasse a consolidação e densificação da Zona B, é atualmente uma zona edificada consolidada, mas com um cariz essencialmente habitacional, sem equipamentos e/ou serviços de hierarquia superior à de unidade de vizinhança, ao contrário do proposto.

\section{Conclusões}

A elaboração do PGU de Vendas Novas apresenta duas importantes inovações. A primeira diz respeito ao próprio modo como foi contratualizado e desenvolvido o trabalho, 
envolvendo, numa experiência única à época, os docentes e alunos do curso de pósgraduação em Planeamento Regional e Urbano da então Universidade Técnica de Lisboa (curso esse que, uns anos mais tarde, daria origem ao primeiro mestrado da universidade) sob a coordenação do Prof. Manuel da Costa Lobo, sendo contratantes a então Direç̧ãoGeral do Planeamento Urbano e a CM de Vendas Novas.

O próprio curso era, em si mesmo, uma novidade no panorama universitário português, já que na altura não existiam cursos de mestrado no país, ou sequer de formação especializada de nível universitário pós licenciatura. Por outro lado, envolvia várias Escolas da mesma universidade, a saber, o Instituto Superior Técnico, a Faculdade de Arquitectura, o Instituto Superior de Economia e Gestão e o Instituto Superior de Agronomia, o que Ihe conferia um carácter interdisciplinar, tanto no que se refere às disciplinas teóricas lecionadas, como na parte prática do curso. Esta era baseada em trabalho de equipa pluridisciplinar (atendendo às diferentes formações de base dos alunos) e centrado num caso concreto de planeamento territorial. O concelho de Vendas Novas e o seu principal aglomerado urbano, constituíram o caso de estudo que serviu para testar novas abordagens ao planeamento urbano e territorial, e permitir a confrontação dos alunos com os procedimentos administrativos associados à elaboração de um plano de urbanização.

O segundo aspecto inovador teve a ver com os conceitos adoptados e a metodologia desenvolvida ao longo do trabalho, que acabaria por ser concluído no âmbito do CESUR, primeiro centro de investigação interdisciplinar da UTL, onde continuaram a trabalhar alguns dos alunos do curso de pós graduação, após a sua conclusão.

Neste contexto sobressai a noção de que o planeamento urbano deve estar enquadrado por uma reflexão sobre o futuro expectável da região em que o território em estudo se insere. Daí que, para definir a vocação e compreender qual o papel e as inter-relações de Vendas Novas nesse espaço mais vasto, se tenha começado por equacionar o desenvolvimento da Área Metropolitana de Lisboa e do eixo Pegões/Vendas Novas/Évora, como um espaço de localização de novas actividades produtivas e logísticas associadas ao crescimento da região polarizada pela $A M L$, passando Évora a constituir uma centralidade secundária que, embora gozando de relativa autonomia em relação à principal metrópole do país, beneficiaria da sua proximidade à capital $(140 \mathrm{~km})$ e da descentralização que então se preconizada para alguns equipamentos de hierarquia superior, nomeadamente nos domínios do ensino superior e da 
saúde. Note-se que este mesmo conceito de uma AML polinucleada veio a ser consagrado no primeiro Plano Regional de Ordenamento do Território (PROT) elaborado para a AML, aprovado pelo governo apenas em 2002, mais de duas décadas depois da conclusão do PGU de Vendas Novas.

Ao nível do PGU propriamente dito, as principais inovações conceptuais e metodológicas incidiram quer numa proposta de plano urbanístico que ultrapassava o mero zonamento dos usos do solo no espaço urbano, quer na introdução do conceito de unidade de planeamento (que seria consagrada na legislação urbanística sob a designação de "Unidade Operativa de Planeamento e Gestão" em 1999), quer na definição de objectivos urbanísticos e morfo-tipologias urbanas para cada um desses espaços a urbanizar.

Em relação à questão do zonamento, é importante relevar que, para além de se ter adoptado uma formalização mais abrangente para os usos do solo, em particular permitindo a mistura de usos do solo nos espaços residenciais (desde que estes fossem compatíveis com a habitação), assinala a localização preferencial de actividades urbanas no espaço qualificado como central, e propõe usos exclusivos nas situações dos espaços industriais e de equipamentos. Por outro lado, em vez de se delimitar de forma precisa as áreas de expansão do aglomerado urbano, apontam-se antes as direcções preferenciais para essa expansão ocorrer, deixando em aberto a sua extensão, a qual dependerá do crescimento demográfico que se vier a verificar e da parte desse crescimento que se conseguiria acomodar através da densificação do espaço urbano infraestruturado existente, política que é privilegiada. Esta opção exigia uma monitorização permanente do Plano, o que também é uma postura inovadora para a época.

Todavia, o aspecto mais inovador é, de facto, a introdução do conceito de "Unidade de Planeamento", onde se definem os objectivos a alcançar em cada subespaço urbano, bem como as orientações que se apontam para a sua concretização, as quais vão para além da explicitação dos usos do solo, para incidirem igualmente em aspectos morfo-tipológicos, de vivência urbana e das relações entre espaço privado e público. Deste modo, deixa-se o necessário grau de liberdade para a gestão urbanística do Plano e para as negociações com a iniciativa privada que poderão contribuir para a sua concretização, sem no entanto deixar de balizar de modo claro essa intervenção. 
Por tudo isto, o PGUVN pode considerar-se um processo urbanístico inovador e uma referência no quadro do planeamento urbano nacional, ao introduzir conceitos e aspectos metodológicos que, anos mais tarde, acabaram por ser consagrados na legislação sobre planeamento físico adoptada pelo País.

\section{Referências Bibliográficas}

COSTA LOBO, Manuel da. Plano de Vendas Novas - Análise. Lisboa: Curso de Planeamento Regional e Urbano, Reitoria da Universidade Técnica de Lisboa, 1979

COSTA LOBO, Manuel da. Plano de Vendas Novas - Propostas. Lisboa: Curso de Planeamento Regional e Urbano, Reitoria da Universidade Técnica de Lisboa, 1980

FRADE, Catarina. A Componente Ambiental no Ordenamento do Território. Lisboa: Conselho Económico e Social, $1999 . \quad$ Disponível em: http://197.249.65.74:8080/biblioteca/bitstream/123456789/296/1/CompAmbOrdTerrit.pdf

FRANÇA, José. O Espaço Ambíguo na Obra de Menez. História da Arte Ocidental 1780-1980. Lisboa: Livros Horizonte, 1987

GONÇALVES, F. Evolução Histórica do Direito do Urbanismo. O Direito do Urbanismo, Lisboa: INA, 1989

GOVERNO PROVISÓRIO DA REPÚBLICA PORTUGUESA. Programa de Política Económica e Social. Lisboa: Imprensa Nacional, 1975

IISED (Instituto Internacional de Engenharia de Sistemas e Desenvolvimento). Herdade do Viveiro da Ajuda - Estudo Prévio. Lisboa, 1982

MALISZ, Bolesław. La formation des systèmes d'habitat: esquisse de la théorie des seuils. Paris: Dunod, 1972

MALISZ, Bolesław. Poland builds new towns. Warsaw: Poland Publishing House, 1962

NUNES DA SILVA, Fernando; SERDOURA, Francisco. Operação de Loteamento Municipal em Vendas Novas. Lisboa: CESUR, 1996

PEREIRA, Margarida; NUNES DA SILVA, Fernando. Modelos de ordenamento em confronto na área metropolitana de Lisboa: cidade alargada ou recentragem metropolitana? Brasil: Cadernos Metrópole, 20, pp. 107-123, 2008

SALGUEIRO, Teresa Barata. Os transportes no desenvolvimento das cidades portuguesas. Povos e Culturas, 2, 113-144. Lisboa: Centro de Estudos dos Povos e Culturas de Expressão Portuguesa, 1987

VIEIRA DE ALMEIDA, Pedro. Ensaio sobre o Espaço da Arquitectura. Ensaio sobre algumas características do espaço em Arquitetura e elementos que o informam. CODA, Porto: ESBAP, 1962. Disponível em: $\underline{\text { https://repositorio- }}$ tematico.up.pt/bitstream/10405/48199/1/CODA_252_pe.pdf 